\title{
19. PLANKTONIC FORAMINIFERAL BIOSTRATIGRAPHY OF PLIOCENE AND QUATERNARY DEPOSITS OF THE EAST PACIFIC RISE AND THE GALAPAGOS SPREADING CENTER DEEP SEA DRILLING PROJECT LEG 54
}

\author{
V. A. Krasheninnikov, Geological Institute of the USSR Academy of Sciences, Moscow, USSR
}

\begin{abstract}
During Leg 54 drilling was carried out in two regions: the Galapagos Spreading Center (GSC) (Sites 424 and 425), and on the western slope of the East Pacific Rise (EPR) (Sites 419 through 423, and 426 through 429) in the equatorial part of the Pacific Ocean. In the first region, the basalts are overlain by Quaternary foraminifer-nannofossil planktonic oozes and hydrothermal clays with tropical assemblages of planktonic foraminifers rich in number of specimens, but somewhat poor in specific composition. The absence of the Globorotalia crassaformis group and some other species prevents subdivision of the Globorotalia truncatulinoides Zone into five subzonal units. On the EPR, the basalts are overlain by foraminifer-nannofossil, nannofossil, and siliceous calcareous oozes, with planktonic foraminifers strongly affected by selective dissolution. At Sites 419 and 420 the section begins with late Pliocene (the Globorotalia tosaensis Zone). To the east, nearer the axial part of the ridge, the basalts are overlain by sediments of Quaternary age. The morphology distribution, frequency of occurrence, stability to selective dissolution, and paleoclimatic significance of selected species of planktonic foraminifers are discussed.
\end{abstract}

\section{INTRODUCTION}

In the eastern equatorial part of the Pacific Ocean (Figure 1), 18 holes were drilled at 11 sites during Leg 54. The sites are associated with two regions of the Pacific Ocean-the western slope of the East Pacific Rise (EPR) (Sites 419-423, 426-429) and the southern slope of the Galapagos Spreading Center (GSC) (Sites 424 and 425). No sediments were recovered at Site 426 . In these regions the basalts of the oceanic basement are covered by young upper Cenozoic sediments, up to 150 -meterthick nannofossil, foraminifer-nannofossil and nannofossil-radiolarian oozes, sometimes argillaceous, with thin interbeds of clays in the upper part of the section; at the GSC, they are supplemented by green hydrothermal clays with iron-manganese fragments. Site data are presented in Table 1; planktonic foraminiferal assemblages were investigated from 221 samples of sediments from cores obtained at these sites.

The first information on the stratigraphy and character of planktonic foraminifers of the upper Cenozoic of the eastern Pacific was obtained on Legs 9 and 16 of the Deep Sea Drilling Project (Hays, Cook, et al., 1972; van Andel, Heath, et al., 1973; Jenkins and Orr, 1972; Kaneps, 1973; Bukry et al., 1973). Directly southeast of Sites 424 and 425 , Sites 156 and 157 were drilled on the Carnegie ridge. Here, upper Miocene, Pliocene, and Quaternary sediments were penetrated above the basalts. The sediments had planktonic foraminifers of moderate to good preservation, but relatively low species diversity and no index species. More diverse are planktonic foraminifers in upper Cenozoic deposits to the north of the GSC-in the Panama Basin and the surrounding ridges of Coiba, Cocos, and on the eastern slope of the EPR (Sites 83, 84, 155, and 158). On the latter's western slope the nearest Site 82 was drilled at a considerable distance southwest of the drilling sites of Leg 54; this hole penetrated upper Miocene, Pliocene, and Quaternary sediments with various well-preserved planktonic foraminifers. Jenkins and Orr (1972) and Kaneps (1973) point out the absence or scarcity of such species as Globorotalia tosaensis and G. truncatulinoides. Therefore, the upper Pliocene sediments are singled out as the Globigerinoides fistulosus or the Globorotalia limbata zones respectively. Quaternary sediments were assigned to the Pulleniatina obliquiloculata Zone. Planktonic foraminiferal assemblages of the upper Cenozoic are characterized by these authors as typically equatorial. In some interbeds, however, Globorotalia inflata was recognized, testifying to cooling and climatic fluctuations.

\section{LATE CENOZOIC STRATIGRAPHY AT LEG 54 SITES}

The stratigraphic subdivision of upper Cenozoic deposits is considered separately for the GSC and the EPR sites.

\section{Galapagos Spreading Center}

In this region, Sites 424 and 425 were drilled at moderate ocean depths ( 2685 to $2850 \mathrm{~m}$ ), much higher than the carbonate compensation depth. Therefore, the 


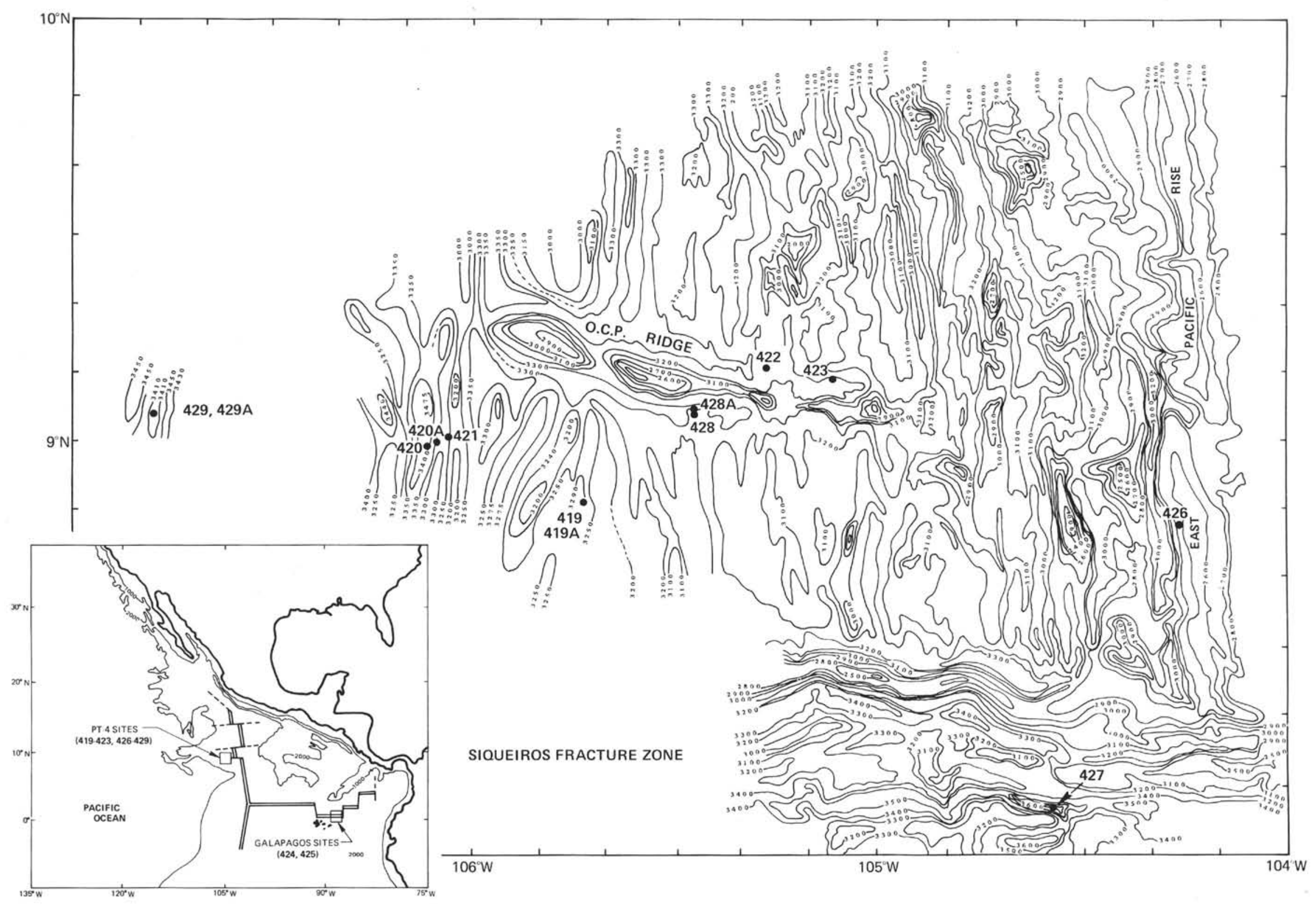

Figure 1. Location of Leg 54 sites. 
TABLE 1

Data on Sites of Leg 54

\begin{tabular}{lcccc}
\hline Holes & Latitude (N) & Longitude (W) & $\begin{array}{c}\text { Water Depth } \\
(\mathrm{m})\end{array}$ & $\begin{array}{c}\text { Thickness of } \\
\text { Sediments } \\
(\mathrm{m})\end{array}$ \\
\hline 419 & $08^{\circ} 55.96^{\prime}$ & $105^{\circ} 41.17^{\prime}$ & 3274 & 35 \\
$419 \mathrm{~A}$ & $08^{\circ} 55.47^{\prime}$ & $105^{\circ} 41.22^{\prime}$ & 3274 & 46 \\
420 & $09^{\circ} 00.10^{\prime}$ & $106^{\circ} 06.77^{\prime}$ & 3381 & 115 \\
$420 \mathrm{~A}$ & $09^{\circ} 00.50^{\prime}$ & $106^{\circ} 06.32^{\prime}$ & 3382 & 63 \\
421 & $09^{\circ} 01.41^{\prime}$ & $106^{\circ} 03.68^{\prime}$ & 3339 & 95 \\
422 & $09^{\circ} 10.59^{\prime}$ & $105^{\circ} 16.27^{\prime}$ & 3247 & 45 \\
423 & $09^{\circ} 08.81^{\prime}$ & $105^{\circ} 06.57^{\prime}$ & 3161 & 42 \\
424 & $00^{\circ} 35.63^{\prime}$ & $86^{\circ} 07.82^{\prime}$ & 2685 & 36 \\
$424 \mathrm{~A}$ & $00^{\circ} 35.33^{\prime}$ & $86^{\circ} 07.81^{\prime}$ & 2708 & 34 \\
$424 \mathrm{~B}$ & $00^{\circ} 35.82^{\prime}$ & $86^{\circ} 07.82^{\prime}$ & 2705 & 32 \\
$424 \mathrm{C}$ & $00^{\circ} 35.93^{\prime}$ & $86^{\circ} 07.82^{\prime}$ & 2699 & 26.7 \\
425 & $01^{\circ} 23.68^{\prime}$ & $86^{\circ} 04.22^{\prime}$ & 2850 & 79 \\
427 & $08^{\circ} 06.79^{\prime}$ & $104^{\circ} 36.35^{\prime}$ & 3834 & 146 \\
428 & $09^{\circ} 02.77^{\prime}$ & $105^{\circ} 26.14^{\prime}$ & 3295 & 66 \\
$428 \mathrm{~A}$ & $09^{\circ} 02.77^{\prime}$ & $105^{\circ} 26.14^{\prime}$ & 3286 & 63 \\
429 & $09^{\circ} 02.01^{\prime}$ & $106^{\circ} 46.35^{\prime}$ & 3406 & 31 \\
$429 \mathrm{~A}$ & $09^{\circ} 02.01^{\prime}$ & $106^{\circ} 45.87^{\prime}$ & 3426 & 31 \\
\hline
\end{tabular}

planktonic foraminiferal assemblages are well preserved and give us a fairly comprehensive picture of the nature of the tropical microfauna. The sediments are of Quaternary age only.

\section{Site 424}

Four holes were drilled at this site (Holes 424, 424A, 424B, and 424C), the sections of which supplement each other. The basalts are overlain by grayish, yellowish, and greenish foraminiferal-nannofossil and siliceous (radiolarians, diatoms, sponge spicules) nannofossil oozes. In the upper part, they alternate with hydrothermal deposits-green clays, and some iron-manganese material. The sediment thickness is up to 36 meters.

The assemblage of planktonic foraminifers in the lower part of the section consists of numerous Neogloboquadrina dutertrei, Globorotalia menardii, Globigerinoides ruber, G. trilobus and common Orbulina universa, Globigerina bulloides, Globorotalia tumida. Such species as Sphaeroidinella dehiscens, Pulleniatina obliquiloculata, Globorotaloides hexagonus, Globigerinoides conglobatus, G. sacculifer, G. elongatus, Globigerinella siphonifera, Hastigerina pelagica, Globigerina rubescens, G. calida praecalida, Globigerinita uvula, G. glutinata, Globorotalia tumida flexuosa, G. ungulata, $G$. cultrata, G. obesa, G. cavernula, $G$. scitula, and $G$. hirsuta occupy a subordinate position. Single specimens of Globorotalia truncatulinoides (Samples 424-4-4, $49-51 \mathrm{~cm}, 424-4-5,31-33 \mathrm{~cm}$, and 424B-4-3, 70-72 cm) occur sporadically. The intervals representing this lower part of the section were from Sample 424-4-1, 31-33 cm to Sample 424-4-6, 49-51 cm; from Sample 424A-3-1, 49$51 \mathrm{~cm}$ to Sample 424A-3-3, 60-62 cm; and from Sample 424B-4-1, 90-92 cm to Sample 424B-4-4, 60-62 cm.

Higher up the section in calcareous oozes, the same species of planktonic foraminifers occur, but with pink Globigerina rubescens, Globigerinoides ruber, and single Globigerina calida calida; the species Globoro- talia truncatulinoides was not identified. Some specimens of Globorotaloides hexagonus occur at the very top of the section (Sample 424B-1-1, 40-42 cm). This upper part is from Sample 424-3-2, $30-32 \mathrm{~cm}$ to Sample 424-3-6, 50-52 cm; from Sample 424A-2-1, $49-51 \mathrm{~cm}$ to Sample $424 \mathrm{~A}-2-2,39-41 \mathrm{~cm}$; and from Sample 424B-1-1, 40-42 cm to Sample 424B-3-5, $110-112 \mathrm{~cm}$.

\section{Site $\mathbf{4 2 5}$}

The basalts are overlain by grayish and greenish foraminifer-nannofossil oozes, 79 meters thick. The middle part of this member abounds in foraminifer-nannofossil oozes with a high content (up to $30 \%$ ) of siliceous skeletons (radiolarians, diatoms, and sponge spicules).

In the interval from Sample 425-3-1, 49-51 cm to Sample 425-6-2, 49-51 cm, planktonic foraminifers are represented by numerous Globorotalia menardii, $G$. tumida, Neogloboquadrina dutertrei, Globigerinoides ruber, G. trilobus, sometimes supplemented with similarly abundant Orbulina universa, Globigerina rubescens, Pulleniatina obliquiloculata. Globorotaloides hexagonus, Globigerinoides conglobatus, G. sacculifer, and Globorotalia ungulata. G. scitula, Globigerina bulloides, Globigerinella siphonifera, and Sphaeroidinella dehiscens are constantly present, although in a minor number of specimens. Globorotalia cavernula, G. hirsuta, Hastigerina pelagica, and Globigerina calida praecalida are sporadic. Single specimens of Globorotalia truncatulinoides occur in two specimens only: Samples 425-3-3, 49-51 cm and 425-5-3, 49-51 cm; scarce, small specimens of Globorotalia tosaensis occur in Samples 425-4-3, 49-51 cm and 425-5-4, 49-51 cm. In Samples 425-3-4, 49-51 cm and 425-3-5, 49-51 cm, Globorotalia inflata and Globigerina bulloides are common; this testifies to a decrease of temperature of surface waters. The presence of Globorotalia crassaformis oceanica and G. crassaformis crassaformis in Sample 425-4-2, 49-51 $\mathrm{cm}$ seems likely to be related to some deterioration of climatic conditions. The lowest beds of the member under question are characterized by scarce Globigerinoides fistulosus (Samples 425-6-1, 49-51 cm and 425-6-2, $49-51 \mathrm{~cm})$. These layers appear to be assignable to the basal part of the Quaternary.

Most of these species also occur in the upper part of the section (interval from Sample 425-1-1, 40-42 cm to Sample 425-2-5, 49-51 cm). Globorotalia truncatulinoides, G. tosaensis, G. crassaformis, G. inflata, and Globigerinoides fistulosus are exceptions. Here numerous pink Globigerinoides ruber and Globigerina rubescens appear combined with scarce Globigerina calida calida. Specimens of Globorotaloides hexagonus and Globorotalia tumida flexuosa occur in the uppermost Sample 425-1-1, 40-42 cm.

\section{East Pacific Rise}

On the western slope of the EPR, Sites 419 through 423 and 426 through 429 were drilled in considerable water depths-3161 to 3834 meters. At all the sites planktonic foraminifers are more or less affected by selective dissolution. At Sites 419 and 420 the sections 
begin with upper Pliocene sediments; at other sites the basalts are overlain by Quaternary oozes.

\section{Site 419}

The basalts are overlain by a member of the pale gray, gray, gray-greenish, and gray-yellowish foraminifer-nannofossil oozes with interbeds of radiolarian-nannoplanktonic oozes in the middle of the section and brown calcareous clays at the top; thickness is 46 meters.

At the base of the section (Sample 419-5-4, 39-41 $\mathrm{cm}$ ), the assemblage of planktonic foraminifers includes scarce Globorotalia tumida, G. menardii, Pulleniatina obliquiloculata, Globorotaloides hexagonus, Sphaeroidinella dehiscens, Globigerinoides ruber, G. trilobus, $G$. conglobatus, $G$. sacculifer, and $G$. obliquus extremus. The presence of $G$. obliquus extremus enables us to attribute the sediments to the uppermost part of the Pliocene, which is confirmed by the presence of discoasters. Tests of foraminifers show clear traces of selective dissolution, fragments of Globorotalia keels being numerous.

In the interval from Sample 419-3-2, 39-41 cm to Sample 419-5-3, 38-40 cm, planktonic foraminifers are poor in number of specimens: Globorotalia tumida, $G$. menardii, Globigerinoides ruber, G. sacculifer, and Pulleniatina obliquiloculata. Neogloboquadrina dutertrei, Globigerinoides trilobus, G. conglobatus, Globigerinita glutinata, Globorotaloides hexagonus, Globorotalia ungulata, G. hirsuta, Orbulina universa, Sphaeroidinella dehiscens, Globigerinella siphonifera, Globigerina bulloides, and $G$. rubescens are very scarce. Noteworthy are traces of dissolution reflected in the abundance of Globorotalia keels. These deposits are of Quaternary age.

Higher in the section, these species are accompanied by Globorotalia fimbriata, G. tumida flexuosa, Globigerina calida calida, pink G. rubescens, and Globigerinoides ruber. Sediments with such an assemblage of planktonic foraminifers belong to the upper Quaternary. There are traces of dissolution, and numerous keels of Globorotalia. This upper interval is from Sample 419-2-2, 29-31 cm to Sample 419-3-1, 40-42 cm, and from Sample 419A-1-1, 39-41 cm to Sample 419A-2-1, $35-37 \mathrm{~cm}$. The species Globorotaloides hexagonus occurs in the uppermost section (Sample 419A-1-1, 39-41 $\mathrm{cm})$.

\section{Site $\mathbf{4 2 0}$}

In this hole, the drill penetrated a thick pile of sediments, 120 meters above the basalts. Foraminifer-nannofossil oozes (nannofossil $45-70 \%$, and foraminifers $5-25 \%$ ) of pale gray, greenish, or yellowish color prevail among the sediments. As the nannofossil content increases up to $75-85$ per cent, or that of siliceous microorganisms (radiolarians, diatoms, silicoflagellates) increases up to $40-50$ per cent, or that of diatoms increases up to $50-80$ per cent, these sediments pass into nannofossil, siliceous nannofossil, and diatom oozes, respectively. In the uppermost part of the section, these oozes alternate with brown calcareous clays.

Planktonic foraminifers are not very numerous and are heavily affected by selective dissolution. Only thickened keels and intercameral sutures remain preserved from Globorotalia tests. This group of plankton serves as the basis for subdivision of the deposits into the upper Pliocene (the Globorotalia tosaensis Zone) and Quaternary (the Globorotalia truncatulinoides Zone). The lower and upper parts are distinguished in Quaternary sediments.

The upper Pliocene (the Globorotalia tosaensis Zone) is established by means of Globorotalia pseudomiocenica, G. pertenuis, and Globigerinoides obliquus extremus, despite the absence of the index species. These species are accompanied by Neogloboquadrina dutertrei, Globorotaloides hexagonus, Globorotalia tumida, G. menardii, G. cultrata, G. scitula, Globigerinoides ruber, G. sacculifer, G. trilobus, G. conglobatus, Orbulina universa, Pulleniatina obliquiloculata, Sphaeroidinella dehiscens, and Globigerinella siphonifera. This interval is from Sample 420-11-2, 50-52 cm to Sample 420-13-5, 39-41 cm. The Pliocene/Quaternary boundary is established conditionally to be below the first sample in which Globorotalia truncatulinoides was identified (Sample 420-10-6, 40-42 cm). However, the last specimens of Pliocene Globorotalia pseudomioceni$c a$ and Globigerinoides obliquus extremus were recognized in Sample 420-12-3, 40-42 cm. Thus, unquestionable Pliocene and unquestionable Quaternary sediments are divided by an interval (from Sample 420-11-2, 50-52 $\mathrm{cm}$ to Sample $420-12-2,40-42 \mathrm{~cm}$, thickness about 12 m) with transitional Pliocene-Quaternary planktonic foraminifers. The age of this interval of sediments remains obscure.

Lower Quaternary deposits are characterized by Globorotalia menardii, G. tumida tumida, Globigerinoides trilobus, G. ruber, G. sacculifer, Orbulina universa, and Neogloboquadrina dutertrei that are accompanied by scarce or even single Pulleniatina obliquiloculata, Globorotaloides hexagonus, Sphaeroidinella dehiscens, Globorotalia cultrata, G. tumida flexuosa, G. ungulata, G. hirsuta, G. scitula, Globigerinoides conglobatus, Globigerinella siphonifera, Turborotalita iota, Globigerina bulloides, G. rubescens, G. calida praecalida, Globigerinita uvula, and G. glutinata. As has already been mentioned, single specimens of Globorotalia truncatulinoides occur in one sample only (Sample $420-10-6,40-42 \mathrm{~cm}$ ). In Samples 420-9-3, 39-41 cm and $420-10-3,40-42 \mathrm{~cm}$, single specimens of Candeina nitida were identified. This lower Quaternary interval is from Sample 420-4-2, 39-41 cm to Sample 420-10-6, 40-42 cm.

In the upper part of the Quaternary, a similar assemblage of planktonic foraminifers is developed. New elements of microfauna include Globorotalia fimbriata, Globigerina calida calida, pink G. rubescens, and Globigerinoides ruber. In Sample 420-4-1, 39-41 cm, single specimens of Globorotalia truncatulinoides occur; the species Globorotaloides hexagonus was observed in the uppermost section studied (Sample $420 \mathrm{~A}-1-1,59-61 \mathrm{~cm})$. The upper Quaternary interval is from Sample 420-1-1, 33-35 cm to Sample 420-4-1, 
$39-41 \mathrm{~cm}$; and from Sample $420 \mathrm{~A}-1-1,59-61 \mathrm{~cm}$ to Sample 420A-1-4, 40-42 cm.

\section{Site 421}

A mudline core in this hole is composed of foraminifer-nannofossil and nannofossil oozes with interbeds of brown calcareous clay. The sediments belong to the upper Quaternary and are characterized by pink Globigerina rubescens and Globigerinoides ruber, as well as Globorotalia fimbriata and Globigerina calida calida. Other species of planktonic foraminifers present are Neogloboquadrina dutertrei, Pulleniatina obliquiloculata, Sphaeroidinella dehiscens, Globorotalia menardii, G. tumida tumida, G. tumida flexuosa, $G$. ungulata, Globorotaloides hexagonus, Orbulina universa, Globigerinoides trilobus, G. ruber (white), G. sacculifer, G. conglobatus, G. tenellus, Globigerinella siphonifera, and Globigerina bulloides. The species Globorotaloides hexagonus is recognized in the uppermost sample (Sample 421-1-1, 40-42 cm). Poor preservation of the tests indicates the influence of selective dissolution; there are numerous fragments of Globorotalia keels.

An additional 85 meters of sediments was washed in this hole during drilling down to the contact with basalts. At the very contact zone, a section of some centimeters of calcareous oozes was taken, but was not examined by us.

\section{Site $\mathbf{4 2 2}$}

Quaternary sediments, about 45 meters thick, are represented by greenish gray, gray, and pale gray foraminifer-nannofossil and nannofossil oozes with scarce interbeds of siliceous nannofossil oozes in the middle part of the section and brown calcareous clays in its top part. The sediments rest on basalts, but recovery was poor at the contact zone. Planktonic foraminifers facilitate a subdivision of Quaternary deposits into two parts.

Predominant in the lower part of Quarternary deposits from Sample 422-3-3, 39-41 cm to Sample 422-5-6, $39-41 \mathrm{~cm}$ are Globorotalia menardii, G. cultrata, G. tumida tumida, Neogloboquadrina dutertrei, Globigerinoides ruber, and G. trilobus; sometimes they are supplemented by Pulleniatina obliquiloculata, Globigerinoides sacculifer, Orbulina universa, and Globorotaloides hexagonus. The rest of foraminiferal species are in minor amounts: Globorotalia ungulata, G. hirsuta, G scitula, G. obesa, Sphaeroidinella dehiscens. Globigerinoides conglobatus, Globigerinella siphonifera, Hastigerina pelagica, Globigerinita uvula, G. glutinata, Globigerina bulloides, $G$. rubescens, and $G$. calida praecalida. In Sample 422-5-3, 39-41 cm there are scarce Globorotalia crassaformis oceanica.

In the upper part of the section from Sample 422-1-1, $39-41 \mathrm{~cm}$ to Sample 422-3-2, 39-41 cm, these species of planktonic foraminifers (except for Globorotalia crassaformis) are accompanied by Globorotalia fimbriata and pink Globigerina rubescens and Globigerinoides ruber.

Calcareous oozes of Hole 422 contain no Globorotalia truncatulinoides; Globorotaloides hexagonus was identified in the uppermost sample of sediments (Sample $422-1-1,39-41 \mathrm{~cm})$.

\section{Site $\mathbf{4 2 3}$}

In this hole, the basalts are overlain by 42 meters of Quaternary foraminifer-nannofossil and nannofossil oozes, interbedded wtih brown calcareous clays at the top. Planktonic foraminifers are not numerous, frequently poorly or moderately preserved because of selective dissolution. Fragments of Globorotalia keels are abundant.

Quaternary deposits of the lower part of the section (from Sample 423-4-2, 40-42 cm to Sample 423-5-4, $40-42 \mathrm{~cm}$ ) are characterized by Globorotalia tumida tumida, G. tumida flexuosa, G. menardii, G. scitula, Neogloboquadrina dutertrei, Globorotaloides hexagonus, Pulleniatina obliquiloculata, Sphaeroidinella dehiscens, Orbulina universa, Globigerinoides trilobus, $G$. ruber, G. sacculifer, G. conglobatus, Globigerina bulloides, and $G$. rubescens. Single specimens of Candeina nitida occur in Sample 423-4-4, 40-42 cm.

In the upper part of the Quaternary (from Sample 423-1-1, 40-42 cm to Sample 423-3-5, 40-42 cm), a similar assemblage of planktonic foraminifers (except for Candeina nitida) is developed. Along with these species, pink Globigerina rubescens and Globigerinoides ruber were identified here, as well as Globorotalia fimbriata, G. ungulata, G. cultrata, G. cavernula, G. subscitula, and Hastigerina siphonifera. Specimens of Globorotaloides hexagonus have been known from the uppermost sample of our material (Sample 423-1-1, $40-42 \mathrm{~cm})$.

As at Hole 422, no Globorotalia truncatulinoides and Globigerina calida calida occur among Quaternary planktonic foraminifers.

\section{Site 427}

This hole, in the deepest trough of the Siqueiros fracture zone, penetrated the thickest pile of Quaternary sediments $(146 \mathrm{~m})$ drilled on Leg 54 . These sediments are represented by alternations of clayey foraminifernannofossil, radiolarian-nannofossil, and diatom-nannofossil oozes; in the upper part of the section there are interbeds of brown calcareous clays. Planktonic foraminifers were selectively dissolved as a consequence of the considerable depth of the ocean $(3834 \mathrm{~m})$, approaching the CCD. In the interval from Sample 427-6-1, $59-61 \mathrm{~cm}$ to Sample 427-8-6, 59-61 cm, a poor foraminiferal assemblage includes Globorotalia menardii, $G$. tumida tumida, G. ungulata, G. scitula, Pulleniatina obliquiloculata, Globorotaloides hexagonus, Sphaeroidinella dehiscens, Neogloboquadrina dutertrei, Globigerinoides trilobus, G. ruber, G. sacculifer, G. conglobatus, Orbulina universa, Globigerinella siphonifera, and Globigerina bulloides.

In the interval from Sample 427-1-1, 3-5 cm to Sample 427-2-3, 6-8 cm, the forementioned species of planktonic foraminifers are accompanied by pink Globigerina rubescens and Globigerinoides ruber. The position of the boundary between these two intervals of sediments with a somewhat different microfauna re- 
mains obscure, because in the interval between Cores 2 and 6 the coring was not continuous, and we did not receive samples of sediments from Cores 3 and 4.

Abundant fragments of keels of Globorotalia tumida and Globorotalia menardii with etched surfaces were observed in all samples.

\section{Site $\mathbf{4 2 8}$}

Here, 66 meters of Quaternary gray and greenish, clayey foraminifer-nannofossil and siliceous (radiolarians, diatoms, silicoflagellates, and sponge spicules) nannofossil oozes with two interbeds of brown, calcareous clays at the top of the section overlie basalts.

The sediments are rather poor in planktonic foraminifers (5-25\%), although their species composition is relatively diverse: Neogloboquadrina dutertrei, Globorotalia menardii, G. tumida tumida, G. ungulata, $G$. scitula, G. hirsuta, Sphaeroidinella dehiscens, Orbulina universa, Pulleniatina obliquiloculata, Globorotaloides hexagonus, Hastigerina pelagica, Globigerinella siphonifera, Globigerinita uvula, G. glutinata, Globigerina quinqueloba, G. bulloides, G. rubescens, Globigerinoides ruber, G. trilobus, G. sacculifer, G. conglobatus, $G$. elongatus, and $G$. tenellus. They are representative of the entire section of Quaternary sediments, and in Sample 428-1-1, 119-121 cm alone a pink Globigerina rubescens is found to accompany them.

In basal layers of this section, scarce specimens of Globigerinoides fistulosus occur (Samples 428-4-6, 99$101 \mathrm{~cm}$ and $428-5-2,99-101 \mathrm{~cm})$. They obviously testify to the early Quaternary age of the sediments. This age is confirmed by rare occurrences of Pterocanium prismatium, a radiolarian species peculiar to the upper Pliocene but passing into the base of Quaternary sediments (Goll, this volume).

\section{Site 429}

During drilling at this site, the Quaternary sediments ( $31 \mathrm{~m}$ thick) were washed down to the contact with the basaltic basement. Only one mudline core was sampled: nannofossil oozes with fairly minor planktonic foraminifers-Sphaeroidinella dehiscens, Neogloboquadrina dutertrei, Globigerinoides ruber, G. trilobus, G. sacculifer, Globorotalia menardii, G. tumida tumida, G. tumida flexuosa, G. scitula, G. ungulata, Pulleniatina obliquiloculata, Globorotaloides hexagonus, Orbulina universa, Globigerinella siphonifera, Globigerina bulloides, and $G$. rubescens.

The correlation of Pliocene and Quaternary sediments of the EPR and the GSC is shown in Figures 2 and 3 , respectively.

\section{ZONAL STRATIGRAPHY OF PLIOCENE AND QUATERNARY DEPOSITS}

The zonal stratigraphy of the Pliocene and Quaternary by means of planktonic foraminifers has advanced considerably in recent years. Several zonal schemes have been suggested for subdivision of sediments of this age (Blow, 1969; Bolli, 1970, Bolli and Premoli Silva, 1973; Berggren, 1973; Rogl and Bolli, 1973; Kennett, 1973; Lamb and Beard, 1972; Rögl, 1974; Saito et al.,
1975, etc.) I believe that the three-membered subdivision of the Pliocene is the most expedient and best grounded: the Globorotalia margaritae evoluta Zone (or the Sphaeroidinella dehiscens-Globoquadrina altispira Zone), the Globorotalia miocenica Zone, and the Globorotalia tosaensis Zone.

Biostratigraphic subdivision of Quaternary sediments formed during a rather short geological period (1.8 m.y.) runs into considerable difficulties. They should be regarded as the Globorotalia truncatulinoides s.1. Zone. Blow (1969) subdivided Quaternary sediments into two zones (it would be more correct to regard them as subzones): Globorotalia truncatulinoides s. str. and Globigerina calida calida-Sphaeroidinella dehiscens excavata. The analysis of deep-sea drilling data shows that these zones (or subzones) have been established in many sections of the Indian (Krasheninnikov, 1976), Atlantic, and Pacific oceans (Krasheninnikov, 1978a). The subdivision of Quaternary sediments (the Globorotalia truncatulinoides Zone) in the Cariaco Basin of the Caribbean Sea is much more detailed with five subzones: Globorotalia crassaformis viola, Globorotalia crassaformis hessi, Globigerina calida calida, Globigerina bermudezi, and Globorotalia fimbriata (Bolli and Premoli Silva, 1973; Rögl and Bolli, 1973). These subzones have since been established for the Mid-Atlantic Ridge (Sites 395 and 396, Legs 45 and 46; Krasheninnikov, 1978b, c), near the western coast of Africa (Sites 366, 367, 368, and 369, Leg 41; Pflaumann and Krasheninnikov, 1978), and in the Timor Trough of the Indian Ocean (Site 262, Leg 41; Rögl, 1974). Such a wide geographical extension of these subzones witnesses to their chronostratigraphic character.

However, a reliable establishment of subzones of Quaternary sediments is only possible when rich assemblages of planktonic foraminifers are available. The impoverishment of the latter because of unfavorable ecological factors, selective dissolution caused by subsiding toward or through the foraminiferal lysocline, or in diagenetic transformations in sediment, can make biostratigraphy difficult. Such impoverished planktonic foraminiferal assemblages characterize the upper Pliocene and Quaternary sediments in the regions of the Leg 54 sites.

Upper Pliocene deposits occur on the western slope of the EPR (Sites 419 and 420). The age of sediments is based on single specimens of Globigerinoides obliquus extremus, Globorotalia pertenuis, and scarce Globorotalia pseudomiocenica. It should be admitted that scarce specimens of these species apparently persisted to the late Pliocene. I assign the sediments concerned to the Globorotalia tosaensis Zone, although the index species itself is missing. An older Pliocene assignment (the Globorotalia miocenica Zone) is hardly probable, because Globorotalia miocenica, G. multicamerata, and representatives of Globoquadrina and Sphaeroidinellopsis are lacking. The tropical assemblage of planktonic foraminifers includes Globorotalia tumida, G. menardii, G. scitula, Sphaeroidinella dehiscens, Pulleniatina obliquiloculata, Orbulina universa, Globorotaloides hexagonus, Globigerinoides ruber, G. conglobatus, G. 


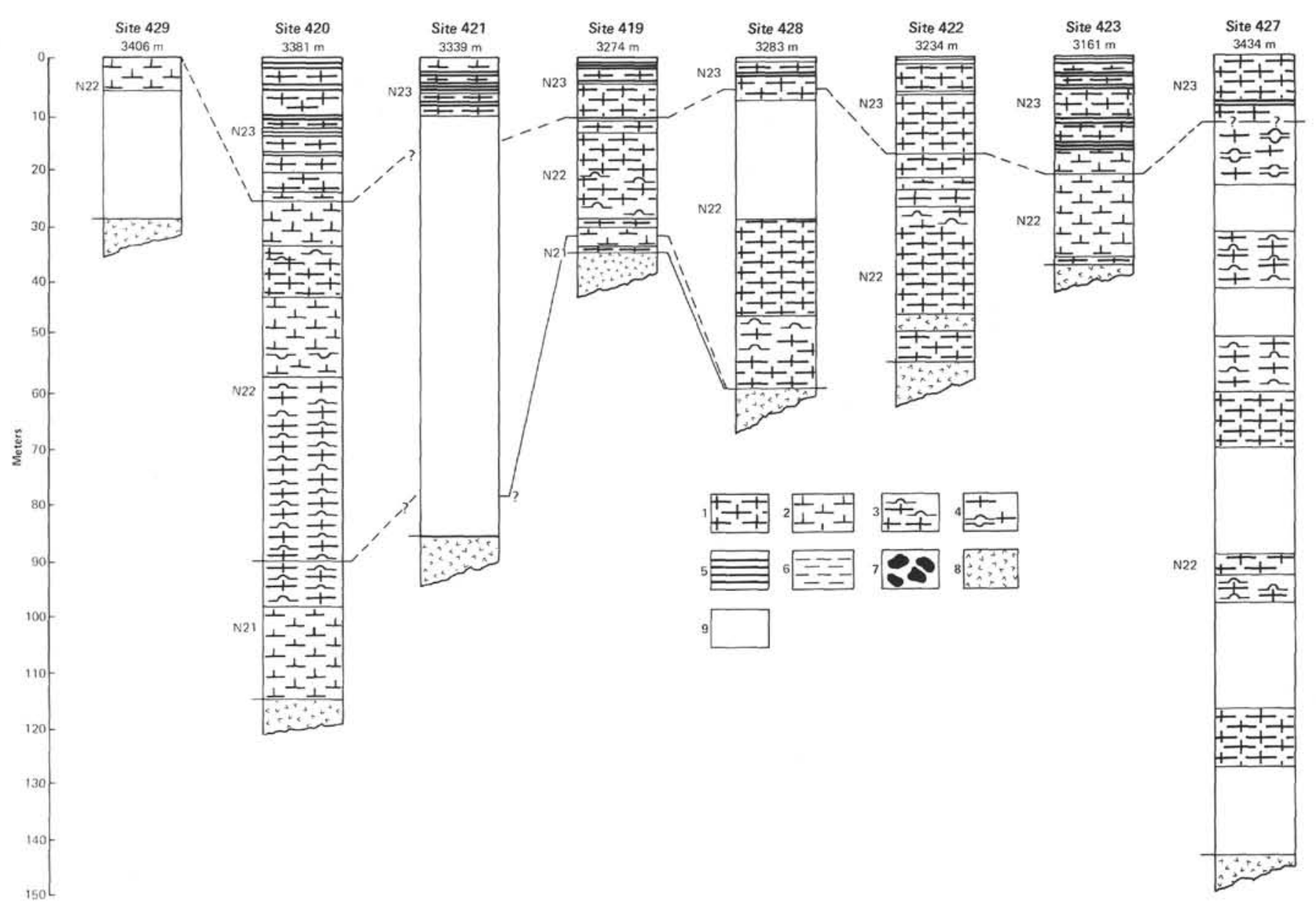

Figure 2. Stratigraphic correlation of the late Pliocene and Quaternary sediments of the East Pacific Rise. Lithologic symbols: 1 = foraminifer-nannofossil ooze (sometimes marly); 2 = nannofossil ooze; 3 = siliceous nannofossil ooze; 4 = calcareous siliceous ooze; 5 = brown calcareous clay; 6 = green hydrothermal clay; $7=$ iron-manganese fragments; 8 = basalts; 9 = washed-down or not-recovered intervals. Stratigraphic symbols: $N .21$ = the Globorotalia tosaensis Zone, upper Pliocene; N.22 = The Globorotalia truncatulinoides Subzone s.str., Quaternary; N.23 = the Globigerina calida calida-Sphaeroidinella dehiscens excavata Subzone, Quaternary.

sacculifer, G. trilobus, Neogloboquadrina dutertrei, and Globigerinella siphonifera. All of these persist in the Quaternary sediments. There are no species peculiar to subtropical and higher latitudes such as Globorotalia crassaformis, G. inflata, Hastigerina pelagica, Globigerinita glutinata, Globigerina bulloides, G. calida, and G. quinqueloba.

The species compositional diversity of Quaternary planktonic foraminifers appears to have been at the expense of a few specimens of subtropical and temperate species. This seems to be related to a general deterioration of climatic conditions in Quaternary time and episodic penetration of colder water masses into the equatorial area. It should be borne in mind however, that we had rather limited upper Pliocene materials from Leg 54.

At the GSC $\left(0^{\circ}-2^{\circ} \mathrm{N}\right)$, planktonic foraminifers were not affected by selective dissolution; they are represented by an equatorial assemblage: predominant Globorotalia tumida tumida, $G$. tumida flexuosa, $G$. menardii, $G$. cultrata, Globigerinoides ruber, G. sacculifer, $G$. conglobatus, Pulleniatina obliquiloculata, Sphaeroid- inella dehiscens, and Neogloboquadrina dutertrei; frequent Globigerinoides trilobus, Globigerinella siphonifera, Hastigerina pelagica, Orbulina universa, Globorotaloides hexagonus, Globorotalia ungulata, $G$. scitula, G. hirsuta, Globigerina bulloides, G. rubescens, and G. calida praecalida; single and sporadic Globorotalia truncatulinoides, $G$. inflata, $G$. crassaformis oceanica, Globigerinita glutinata, G. uvula, and Globigerina quinqueloba. Planktonic foraminifers enable us to subdivide the Quaternary deposits of Sites 424 and 425 into two divisions: the lower division with the forementioned assemblage of species associated with single Globorotalia tosaensis, as well as single Globigerinoides fistulosus at the base of the section, and an upper division where this assemblage is accompanied by Globigerina calida calida, pink G. rubescens, and Globigerinoides ruber.

On the western slope of the EPR $\left(8^{\circ}-9^{\circ} \mathrm{N}\right)$, planktonic foraminifers unexpectedly display extensive selective dissolution. In smear slides of sediments, the foraminiferal content is rather significant $(10 \%-25 \%$, rarely $30 \%-50 \%$ ). However, after the washing proc- 


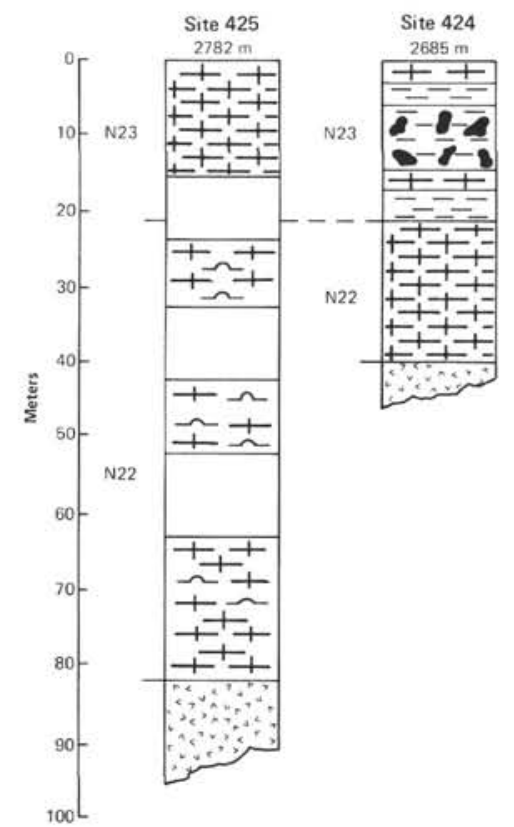

Figure 3. Stratigraphic correlation of the Quaternary sediments of the Galapagos Spreading Center. Lithologic and stratigraphic symbols are the same as for Figure 2.

ess, this amount is rather small - some hundreds of specimens, often only some tens of specimens. They are accompanied by mass accumulations of keel fragments belonging to Globorotalia. This is because semidissolved, fragile, thin walls of foraminiferal tests change into powder (micarb) after washing, but thickened keels remain preserved. Such corroded specimens of Globorotalia tumida and $G$. menardii with etched surfaces are shown in Plate 4, Figure 12, and Plate 6, Figure 5. It should be noted, however, that along with corroded tests, scarce well-preserved specimens occur; this is hardly explicable.

On the whole, the Quaternary deposits of the EPR are characterized by resistant species - Globorotalia tumida, G. menardii, G. scitula, G. hirsuta, Sphaeroidinella dehiscens, Pulleniatina obliquiloculata, Neogloboquadrina dutertrei, and Globorotaloides hexagonus. Specimens of other species are not numerous - Globigerinoides ruber, G. sacculifer, G. conglobatus, G. elongatus, G. tenellus, G. trilobus, Orbulina universa, Globigerinella siphonifera, Hastigerina pelagica, Globorotalia cultrata, G. ungulata, Globigerina bulloides, G. rubescens and G. calida praecalida. Very scarce are Globorotalia truncatulinoides, G. cavernula, G. subscitula, $G$. crassaformis crassaformis, G. crassaformis oceanica, Candeina nitida, Globigerinita glutinata, G. uvula, and Globigerina quinqueloba.

The Quaternary deposits of this region can be subdivided into the same two divisions as in the GSC: the lower division with the forementioned species of planktonic foraminifers, and the upper division, where they are accompanied by Globorotalia fimbriata, Globigerina calida calida, and pink G. rubescens, and Globigerinoides ruber.
Thus, at EPR sites drilled on Leg 54, upper Pliocene and Quaternary deposits are characterized by impoverished assemblages of planktonic foraminifers. Absence or extremely rare occurrence of Globorotalia tosaensis and $G$. truncatulinoides makes definition of the Pliocene/Quaternary boundary difficult. The Quaternary is subdivided into two divisions, the lower of which is likely to correspond to the Globorotalia truncatulinoides s.str. Zone (Subzone) and the upper to the Globigerina calida calida-Sphaeroidinella dehiscens excavata Zone (Subzone) after Blow's terminology. An exact determination of the boundary between these zones (subzones) is difficult owing to rare occurrence of specimens of Globigerina calida calida and absence of Hastigerina (Bolliella) adamsi. Even more noteworthy is that this boundary occupies a fixed position relative to the radiolarian zonal scale (Goll, this volume). It is consistently within the Amphirhopalum ypsilon Zone, between one third and halfway from its top (Sites 419, 420, 422, 423, 425, 427 , and 428 ). Where only younger sediments of the Collosphaera tuberosa radiolarian Zone were penetrated, the Globigerina calida calida-Sphaeroidinella dehiscens excavata Zone alone could be identified by means of foraminifers (Site 421). Where the sediments of the lower Amphirhopalum ypsilon radiolarian Zone occur near the sediment surface, only the Globorotalia truncatulinoides s.str. Subzone can be established using foraminifers (Site 429).

The Globorotalia truncatulinoides s.str. Subzone of Blow (1969) corresponds to the Globorotalia crassaformis viola and Globorotalia crassaformis hessi subzones of Bolli and Premoli Silva (1973). The recognition of the two latter subzones in the region of Leg 54 studies is impossible, as these subspecies of $G$. crassaformis are entirely missing.

The Globigerina calida calida-Sphaeroidinella dehiscens excavata Subzone of Blow (1969) can be correlated to the Globigerina calida calida, Globigerina bermudezi, Globorotalia fimbriata subzones of Bolli and Premoli Silva (1973). The boundary of the Globigerina calida calida and Globigerina bermudezi subzones is recognized according to disappearance of Globorotalia tumida flexuosa and Globorotaloides hexagonus, and the boundary of the Globigerina bermudezi and Globorotalia fimbriata subzones by appearance of Globorotalia fimbriata in the base of the latter. All three index species occur in the Leg 54 sediments, but distinguishing the Globigerina calida calida, Globigerina bermudezi, and Globorotalia fimbriata subzones does not appear feasible. The fact is that Globorotalia fimbriata, G. tumida flexuosa, and Globorotaloides hexagonus occur together, the latter two species having been recognized in the uppermost samples $(30-40 \mathrm{~cm}$ below the sediment surface). One might therefore presume that our data on the stratigraphic ranges of Globorotalia fimbriata, $G$. tumida flexuosa, and Globorotaloides hexagonus require revision. I believe, however, that the unusual joint occurrence of these three index species is a consequence of extreme mechanical disturbance of a normal succession of weakly consolidated sediments in the process of drilling; the thin sedimentary cover above the basalts 
did not favor the stabilization of the column of drilling pipes.

Comparison of stratigraphic data obtained from Legs 54,16, and 9 in the eastern equatorial area of the Pacific Ocean shows their great similarity.

Kaneps (1973) points out the absence of Globorotalia tosaensis and G. truncatulinoides in upper Pliocene and Quaternary eastern equatorial Pacific sediments. Therefore, he defined upper Pliocene sediments on the basis of the Globorotalia limbata Zone, and Quaternary sediments on the basis of the Pulleniatina obliquiloculata Zone. He recognized the Pliocene/Quaternary boundary through disappearance of Globigerinoides obliquus and Globorotalia limbata, a synonym of the latter being $G$. pseudomiocenica. South of Carnegie Ridge (Site 157, oceanic depth $1591 \mathrm{~m}$ ), planktonic foraminifers have moderate to good preservation, but their species diversity is low and some index species are missing. On Coiba Ridge (Site 155), where the depth is larger $(2752 \mathrm{~m})$, planktonic foraminifers show obvious traces of dissolution; their impoverished assemblage includes mostly resistant species.

Jenkins and Orr (1972) also speak of the extreme scarcity or absence of Globorotalia tosaensis and $G$. truncatulinoides. They consider that upper Pliocene sediments belong to the Globigerinoides fistulosus Zone, with the Pliocene/Quaternary boundary determined by the disappearance of this species; Quaternary deposits correspond to the Pulleniatina obliquiloculata Zone. In the Panama Basin (Site 84) and on the western slope of the EPR (Site 83), some interbeds of Quaternary deposits contain Globorotalia inflata, this testifying to climatic cooling.

The absence of Globorotalia truncatulinoides, G. tosaensis, and the $G$. crassaformis group in Pliocene Quaternary deposits of the GSC appears to be related to the equatorial position of the region; on the western slope of the EPR $\left(9^{\circ} \mathrm{N}\right)$ it is more probably the result of selective dissolution. In any case, at the same latitude in the Caribbean Sea $\left(10-11^{\circ} \mathrm{N}\right)$ and in the Timor Trough of the Indian Ocean $\left(11^{\circ} \mathrm{S}\right)$ the first two species are frequent, and the Globorotalia crassaformis group is successfully used for the subzonal division of lower Quaternary sediments. Each zone is recognized through an assemblage of planktonic foraminifers, the composition of which undergoes variations depending upon climatic belts, local ecological conditions, and other reasons. Therefore, I believe that absence of one or another species should not serve as the basis for creation of new zonal units. Stratigraphic studies in the World Ocean necessitate unification of zonal scales, as well as zonal names. I consider it entirely permissible to use the Globorotalia tosaensis and Globorotalia truncatulinoides zones in the zonal scale of Pliocene Quaternary deposits of the eastern equatorial part of the Pacific Ocean.

\section{SYSTEMATIC PALEONTOLOGY}

This section contains brief remarks on some selected species of planktonic foraminifers concerning their morphological peculiarities, stratigraphic and paleoclimatic importance, frequency of occurrence, degree of preservation, etc.
Genus GLOBIGERINOIDES Cushman, 1927

Globigerinoides elongatus (d'Orbigny)

(Plate 1, Figures 1-3)

This species was recognized in Quaternary deposits of the Galapagos Spreading Center and East Pacific Rise, but always as scarce, well-preserved specimens. $G$. elongatus differs from elongated specimens of $G$. ruber in presence of only one secondary apertural opening on the last chamber (see Plate 1, Figure 4 for comparison).

\section{Globigerinoides ruber (d'Orbigny)}

(Plate 1, Figures 4-6)

It is widely distributed in upper Pliocene and Quaternary sediments of the Leg 54 region, and frequently forms appreciable accumulations of well- or moderately well preserved tests. Quaternary pink-colored varieties were recognized in the Globigerina calida calida-Sphaeroidinella dehiscens excavata Subzone only.

\section{Globigerinoides sacculifer (Brady)}

(Plate 1, Figures 7-9)

Few specimens are observed in upper Pliocene and Quaternary deposits of the region concerned. This species makes up an appreciable part of planktonic foraminiferal paleocoenoses in only certain samples.

\section{Globigerinoides obliquus obliquus Bolli}

(Plate 1, Figures 10, 11)

Very scarce specimens in upper Pliocene deposits (the Globorotalia tosaensis Zone) of the East Pacific Rise (Sites 419, 420), with compact coiling of chambers, the last of them being slightly oblique. Some specimens with a looser arrangement of chambers approximate $G . o b$ liquus extremus Bolli and Bermudez, but not many specimens make the differentiation of subspecies difficult.

\section{Globigerinoides fistulosus (Schubert)}

(Plate 1, Figures 12, 13)

Single specimens with fistules arranged in line were recognized on basal layers of the Quaternary of the Galapagos Spreading Center (Site 425) and the East Pacific Rise (Site 428). Higher up the section this species is totally absent. Thus, we must assume that the species stops its existence at the base of Quaternary deposits, although the maximum of its development corresponds to the middle part of the Pliocene.

\section{Globigerinoides trilobus (Reuss)}

(Plate 1, Figures 17-19)

This species is commonly found in upper Pliocene and Quaternary deposits of the region studied. The tests are usually well preserved.

\section{Globigerinoides conglobatus (Brady)}

(Plate 1, Figures 14-16)

This is a usual component of planktonic foraminiferal assemblages of the upper Pliocene and Quaternary; the number of specimens is, however, not large. Considerable accumulations are formed only in some samples of Quaternary deposits of the Galapagos Spreading Center. On the East Pacific Rise the tests frequently show traces of dissolution.

\section{Globigerinoides tenellus Parker}

(Plate 2, Figure 1)

This is a scarce species in Quaternary deposits of the region concerned in Leg 54. The general pattern of the test, large primary aperture, and small secondary apertures on the spiral side correspond to a typical $G$. tennellus; yet, the specimens are characterized by a somewhat different microstructure of the wall (fine porosity and pustules on the surface).

\section{Genus ORBULINA d'Orbigny, 1839 \\ Orbulina universa d'Orbigny \\ (Plate 2, Figure 4)}

A common species of planktonic foraminifers from upper Pliocene and Quaternary deposits of Leg 54 material, it always occupies a subordinate position in an assemblage of planktonic foraminifers. 
Genus GLOBIGERINITA Brönnimann, 1951

Globigerinita glutinata (Egger)

(Plate 2, Figures 5-10)

This temperate to cool-water species is a scarce component of planktonic foraminiferal assemblages in Quaternary deposits of the eastern equatorial part of the Pacific Ocean. The character of convex bulla and the number of apertures are variable (Figures 6, 7, 8, and 10). For comparison, we observe that the boreal Globigerinita uvula (Ehrenberg) is generally found as single specimens.

\section{Genus CANDEINA d'Orbigny, 1839 \\ Candeina nitida d'Orbigny \\ (Plate 2, Figures 11, 12)}

Single specimens of this species were recognized in Quaternary sediments of the East Pacific Rise (Sites 420 and 423).

\section{Genus GLOBIGERINELLA Cushman, 1927 \\ Globigerinella siphonifera (d'Orbigny)}

(Plate 2, Figures 13-15)

This is a common species of planktonic foraminifers in upper Pliocene and Quaternary deposits of the Galapagos Spreading Center and the East Pacific Rise. By numbers of specimens it occupies a subordinate position. In most cases initial whorls are clearly trochespirally coiled. Owing to this fact, the lateral sides noticeably differ from one another (Figures 13 and 14).

\section{Genus HASTIGERINA Thomson, 1876 \\ Hastigerina pelagica (d'Orbigny) \\ (Plate 2, Figures 16, 17)}

Scarce specimens of this species with a biumbilicate involute and planispiral test, inflated last chamber, and broad aperture are developed in Quaternary deposits of the region of Leg 54 studies.

\section{Genus GLOBIGERINA d'Orbigny, 1826 \\ Globigerina bulloides d'Orbigny \\ (Plate 2, Figures 18-21)}

Typical specimens of this species in upper Pliocene sediments of Sites 419 and 420 have not been recognized. In Quaternary deposits of the region concerned the species becomes common, but always occupies a subordinate position. The number of specimens of this temperate to cool-water inhabitant appreciably increases in some interbeds, where it is accompanied by Globorotalia inflata and $G$. crassaformis (Sites 422 and 425 ).

\section{Globigerina calida calida Parker}

(Plate 3, Figures 1-7)

This subspecies is characterized by a rapid increase of chamber dimensions, radial elongations, and broad umbilicus. It is representative of the upper part of Quaternary deposits in the region of studies - the Globigerina calida calida - Sphaeroidinella dehiscens excavata Subzone. However, the species occurs in a small number of specimens, making differentiation of $G$. calida praecalida and $G$. calida calida difficult; this especially concerns specimens with intermediate morphological properties (Figures 5, 7).

\section{Globigerina? quinqueloba Natland}

(Plate 3, Figure 8)

This distinctive cool-water indicator is present as single specimens in Quaternary deposits of the region studied.

\section{Globigerina rubescens Hofker \\ (Plate 3, Figures 9-11)}

The species is invariably present in planktonic foraminiferal assemblages from Quaternary deposits of the region studied, but the number of its specimens is not great (white variety). Pink and pinkish specimens are representative elements of microfauna of upper Quaternary sediments (the Globigerina calida calida - Sphaeroidinella dehiscens excavata Subzone). The tests are characterized by good preservation.

\section{Genus SPHAEROIDINELLA Cushman, 1927}

Sphaeroidinella dehiscens excavata Banner and Blow (Plate 3, Figures 12-14)

This variety is characterized by widely open, highly arc-shaped, dorsal and ventral apertures. This enables one to see chambers of the inner whorl. It is peculiar to the upper part of Quaternary deposits, to the Globigerina calida calida - Sphaeroidinella dehiscens excavata Subzone. The number of specimens in a foraminiferal assemblage is not large.

The variety Sph. dehiscens dehiscens is developed in upper Pliocene and Quaternary sediments of the Leg 54 region. The number of specimens is not large either. On the western slope of the East Pacific Rise, fragments of this species tests frequently occur. This witnesses to a strong influence of selective dissolution.

\section{Genus GLOBOROTALOIDES Bolli, 1957 \\ Globorotaloides hexagonus (Natland)}

(Plate 3, Figures 15-18)

This is a typical element of tropical assemblages of planktonic foraminifers in the eastern equatorial part of the Pacific Ocean. In fact, it occurs in each sample, the number of specimens being appreciable. The tests are always well preserved both in upper Pliocene and Quaternary sediments. Specimens of this species have been recognized in the uppermost samples studied by us $(30-40 \mathrm{~cm}$ below the oceanic bottom). Nevertheless, disturbance of the normal succession of slightly consolidated sediments by a heavy column of drilling pipes is quite probable.

\section{Genus NEOGLOBOQUADRINA Bandy, Frerichs and Vincent, 1967 \\ Neogloboquadrina dutertrei (d'Orbigny) s.l. (Plate 4, Figures 1-3)}

This is one of the most widespread species of planktonic foraminifers in upper Pliocene and Quaternary sediments of the Galapagos Spreading Center and the East Pacific Rise. It is characterized by good preservation of tests; low-conic specimens strongly predominant; the highly conic variety is almost absent.

\section{Genus PULLENIATINA Cushman, 1927 \\ Pulleniatina obliquiloculata (Parker and Jones) \\ (Plate 4, Figures 8-10)}

Few specimens of this species were recognized in many samples of upper Pliocene and Quaternary sediments in the region of Leg 54 studies. The tests are well preserved.

\section{Genus GLOBOROTALIA Cushman, 1927 \\ Globorotalia inflata (d'Orbigny) \\ (Plate 4, Figures 4-7)}

This representative of the microfauna of temperate latitudes is almost absent in tropical assemblages of planktonic foraminifers from Leg 54 materials. It is noteworthy that its rather numerous specimens were observed in the Galapagos Spreading Center (Hole 425) in an interbed of sediments (Core 3, Sections 4 and 5) within lower Quaternary deposits (the Globorotalia truncatulinoides Subzone s. str.). Here this species is accompanied by numerous Globigerina bulloides and single Globorotalia truncatulinoides. On the whole, this testifies to encroachment of cold water masses.

\section{Globorotalia tumida flexuosa (Koch)}

(Plate 4, Figure 11)

This is a typical component of tropical assemblages of planktonic foraminifers from Quaternary deposits of the Galapagos Spreading Center and the East Pacific Rise.By number of specimens it is scarcer than $G$. tumida tumida. The tests are characterized by different degrees of preservation, many of them being strongly corroded. This subspecies was also observed in samples occurring at a distance of $30-40 \mathrm{~cm}$ below the oceanic bottom, but mechanical mixing of loose sediments is quite probable. 
Globorotalia tumida tumida (Brady)

(Plate 4, Figures 12-15)

This is a widely distributed species in upper Pliocene and Quaternary sediments of the region of Leg 54 studies. Many of the tests are strongly corroded. Abundant accumulations of thickened keels belonging to $G$. tumida tumida (and $G$. tumida flexuosa too) testify to multiplicity of this species.

\section{Globorotalia crassaformis oceanica Cushman and Bermudez}

(Plate 5, Figures 1-4)

This variety is characterized by a robust test with inflated chambers, rounded peripheral margin, small but distinct umbilicus, and almost subrectangular equatorial outline. Single specimens were found in lower Quaternary deposits (the Globorotalia truncatulinoides Subzone s. str.) of the East Pacific Rise (Site 422) and Galapagos Spreading Center (Site 425).

\section{Globorotalia truncatulinoides (d'Orbigny)}

(Plate 5, Figures 5-8)

This is an extremely scarce species of planktonic foraminifers from Quaternary deposits of the East Pacific Rise (Site 420) and Galapagos Spreading Center (Holes 424, 424B, 425).

\section{Globorotalia fimbriata (Brady) \\ (Plate 5, Figures 9-12)}

Typical specimens of this species with a thin (Figure 11) four- or five-chambered test and peculiar "spinose" keel are frequent in upper Quaternary sediments (the Globigerina calida calida-Sphaeroidinella dehiscens excavata Subzone) of the East Pacific Rise (Sites 420, 421, 422 , and 423). The stratigraphic distribution of this species is confined to the Holocene (Rogl and Bolli, 1973). In the materials of Leg 54 this species is recognized in sediments that make up the upper half to twothirds of the thickness of the forementioned subzone; this phenomenon is likely to be related to disturbance and contamination of sediments by drilling.

\section{Globorotalia pertenius Beard}

(Plate 5, Figures 13, 14)

Scarce specimens of this species with a multichambered test, narrow chambers and thickened spiral suture were found in the upper Pliocene of the East Pacific Rise (Site 420). This species appears to have stopped its existence in the Globorotalia tosaensis Zone, but not in underlying deposits as was previously thought. The recorded specimens differ somewhat from typical representatives of $G$. pertenuis. In any case, they belong to the $G$. pertenuis $-G$. multicamerata group.

\section{Globorotalia menardii (Parker, Jones and Brady)}

(Plate 6, Figures 1-7)

A standard species of planktonic foraminifers from upper Pliocene and Quaternary deposits in the region of Leg 54 studies, it occurs in almost all samples of sediments; the numbers of specimens is sometimes large. The latter are frequently affected by selective dissolution, and corroded (Figure 5).

\section{Globorotalia pseudomiocenica Bolli and Bermudez}

(Plate 6, Figures 8-10)

Not many specimens of this species have been recognized in upper Pliocene deposits (the Globorotalia tosaensis Zone) of the East Pacific Rise (Site 420). The species appears to have stopped its existence in the Pliocene top. It is characterized by a slightly lobulate outline, slightly convex spiral side, and much more convex ventral side. Some authors consider it as a synonym to $G$. limbata (Fornasini). Not being concerned with the problems of taxonomy, we will state only that " $G$. limbata" does not pass beyond the Pliocene/Quaternary boundary.

\section{Globorotalia cavernula Bé}

(Plate 6, Figures 14-16)

A small test has slightly lobulate outline, flat spiral, and high umbonal side; the peripheral margin is non-keeled, relatively acute, with distinctly deep umbilicus. This boreal species was established as single specimens in Quaternary sediments of the East Pacific Rise (Site 423) and the Galapagos Spreading Center (Sites 424 and 425).

\section{Globorotalia ungulata Bermudez \\ (Plate 6, Figures 11-13)}

Typical specimens of this species have an elongated test (Figure 11) with a high umbonal side (Figure 13); less frequently the outline of the test is oval (Figure 12). The keel is well pronounced. The species has been observed throughout the pile of Quaternary deposits of the East Pacific Rise and the Galapagos Spreading Center, although the number of specimens is small.

\section{Globorotalia hirsuta (d'Orbigny)}

(Plate 7, Figures 1-3)

A subrectangular test with four chambers in the last whorl is characterized by an acute peripheral margin with a thin distinct carina (Figure 3). In Quaternary deposits of the East Pacific Rise the specimens of this species are sporadic, whereas in synchronous sediments of the Galapagos Spreading Center they are more common.

\section{Globorotalia scitula (Brady)}

(Plate 7, Figures 4-6)

This species is invariably recognized in planktonic foraminiferal assemblages from upper Pliocene and Quaternary deposits of the region under study. As a rule, the tests are well preserved.

\section{Globorotalia subscitula Conato}

(Plate 7, Figures 7-12)

Not many specimens of the given species were found in the basal layers of Quaternary deposits of the East Pacific Rise (Sites 419 and 420). According to the data presented by Blow (1969), G. subscitula is peculiar to tropical and temperate areas, disappearing in the top of the Pliocene. The specimens concerned are attributed somewhat conventionally to $G$. subscitula.

\section{Globorotalia cultrata (d'Orbigny)}

(Plate 7, Figures 13-19)

A flattened, almost equally biconvex test is characterized by a gradual increase of whorls, a thin wall, and relatively thin keel. The species is common to Quaternary deposits of the region of Leg 54 studies. The tests are frequently affected by selective dissolution.

\section{ACKNOWLEDGMENTS}

The author thanks Yu. I. Dmitriev (petrologist of Leg 54, Moscow) for making available the material for investigation. Scanning-electron photomicrographs were made at the Geological Institute of the USSR Academy of Sciences, Moscow, by N. D. Serebrennikova and A. I. Nikitin, to whom the author expresses his sincere gratitude.

\section{REFERENCES}

Berggren, W. A., 1973. The Pliocene time-scale: calibration of planktonic foraminiferal and calcareous nannoplankton zones. Nature, v. 243, p. 391-397.

Blow, W. H., 1969. Late Middle Eocene to Recent planctonic foraminiferal biostratigraphy. Proceedings of the First International Conference on Planctons and Microfossils: Geneva, 1967, p. 199-421.

Bolli, H. M., 1970. The foraminifera of Sites 23-31, Leg 4. In Bader R. G., Gerard R. D., et al., Initial Reports of the Deep Sea Drilling Project, v. 4: Washington (U. S. Government Printing Office), p. 577-643.

Bolli, H. M., and Premoli Silva, I., 1973. Oligocene to Recent planktonic foraminifera and stratigraphy of Leg 15 Sites in the Caribbean Sea. In Edgar T. N., Saunders J. B., et al., Initial Reports of the Deep Sea Drilling Project, v. 15: Washington (U. S. Government Printing Office), p. 475-497.

Bukry, D., Dinkelman, M. G., and Kaneps, A. G., 1973. Biostratigraphy of the equatorial East Pacific Rise. In van Andel Tj. H., Heath, G. R., et al., Initial Reports of the Deep Sea Drilling Project, v. 16: Washington (U. S. Government Printing Office), p. 915-936. 
Hays, J. D., Cook H. E., et al., 1972. Initial Reports of the Deep Sea Drilling Project, v. 9: Washington (U. S. Government Printing Office).

Jenkins, D. G., and Orr, W. N., 1972. Planktonic foraminiferal biostratigraphy of the eastern equatorial Pacific, Leg 9. In Hays J. D., Cook H. E., et al., Initial Reports of the Deep Sea Drilling Project, v. 9: Washington (U. S. Government Printing Office), p. 1059-1193.

Kaneps, A. G., 1973. Cenozoic planktonic foraminifera from the eastern equatorial Pacific Ocean. In van Andel Tj. H., Heath G. R., et al., Initial Reports of the Deep Sea Drilling Project, v. 16: Washington (U. S. Government Printing Office), p. 713-746.

Kennett, J. P., 1973. Middle and Late Cenozoic planktonic foraminiferal biostratigraphy of the Southwest Pacific, DSDP Leg 21. In Burns, R. E., Andrews, J. E., et al., Initial Reports of the Deep Sea Drilling Project, v. 21: Washington (U. S. Government Printing Office), p. 575-639.

Krasheninnikov, V. A., 1976. Importance of oceanic deposits for working out a stratigraphic scale of Mesozoic and Cenozoic (Indian Ocean). Questions of Micropaleontology, No. 19 , p. 124-227 (in Russian).

, 1978a. Importance of oceanic deposits for working out a stratigraphic scale of Mesozoic and Cenozoic (Pacific and Atlantic Oceans). Ibid., No. 21, p. 42-161 (in Russian). 1978b. Stratigraphy by means of planktonic foraminifers, of Neogene and Quaternary sediments near the crest of the Mid-Atlantic ridge, DSDP Sites 395 and 396. In Melson, W. G., Rabinowitz, P. D., et al., Initial Reports of the Deep Sea Drilling Project, v. 45: Washington (U. S. Government Printing Office), p. 319-322. ,1978c. Stratigraphy and planktonic foraminifers of Neogene and Quaternary sediments of Site 396, Leg 46 of
DSDP. In Dmitriev, L., Heirtzler J., et al., Initial Reports of the Deep Sea Drilling Project, v. 46: Washington (U. S. Government Printing Office), p. 409-414.

Lamb, J. L., and Beard, J. H., 1972. Late Neogene planktonic foraminifers in the Caribbean, Gulf of Mexico, and Italian stratotypes. The University of Kansas Paleontological Contributions, Article 57 (Protozoa, art. 8), p. 1-103.

Pflaumann U., and Krasheninnikov, V. A., 1978. Quaternary stratigraphy and planktonic foraminifera of the Eastern Atlantic, Deep Sea Drilling Project, Leg 41. In Lancelot, Y., Seibold, E., et al., Initial Reports of the Deep Sea Drilling Project, Supplement to v. 41: Washington (U. S. Government Printing Office), p. 883-912.

Rögl, F., 1974. The evolution of the Globorotalia truncatulinoides and Globorotalia crassaformis group in the Pliocene and Pleistocene of the Timor trough, DSDP Leg 27, Site 262. In Veevers J. J., Heirtzler, J. R., et al., Initial Reports of the Deep Sea Drilling Project, v. 27: Washington (U. S. Government Printing Office), p. 743-767.

Rögl, F., and Bolli, H. M., 1973. Holocene to Pleistocene planktonic foraminifera of Leg 15, Site 147 (Cariaco Basin [Trench], Caribbean Sea) and their climatic interpretation. In Edgar, N. T., Saunders, J. B., et al., Initial Reports of the Deep Sea Drilling Project, v. 15: Washington (U. S. Government Printing Office), p. 553-615.

Saito, T., Burckle L. H., and Hays, J. D., 1975. Late Miocene to Pleistocene biostratigraphy of equatorial Pacific sediments. In Saito, T. and Burckle, L. H. (Eds.), Late Neogene Epoch Boundaries: Micropal., Spec. Publ. 1: New York (Micropaleontology Press), p. 226-244.

van Andel, Tj. H., Heath, G. R., et al., 1973. Initial Reports of the Deep Sea Drilling Project, v. 16: Washington (U. S. Government Printing Office).

\section{PLATE 1}

Figures 1-3 Globigerinoides elongatus (d'Orbigny). Sample 420-3-2, 39-41 cm, Quaternary, N23. ×96.

Figures 4-6 Globigerinoides ruber (d'Orbigny). Sample 420A$1-3,40-42 \mathrm{~cm}$, Quaternary, N23. $\times 96$.

Figures 7-9 Globigerinoides sacculifer (Brady). Sample 425-3-3, 49-51 cm, Quaternary, N22. $\times 96$.

Figures 10, 11 Globigerinoides obliquus obliquus Bolli. Sample 420-12-5, 40-42 cm, upper Pliocene, N21. $\times 77$.

Figures 12, 13 Globigerinoides fistulosus (Schubert). Sample 4256-2, 49-51, Quaternary, N22. $\times 96$.

Figures 14-16 Globigerinoides conglobatus (Brady). Sample 4223-4, 29-31 cm, Quaternary, N22. ×96.

Figures 17-19 Globigerinoides trilobus (Reuss). Sample 422-3-2, $39-41 \mathrm{~cm}$, Quaternary, N22. $\times 96$. 
PLATE 1
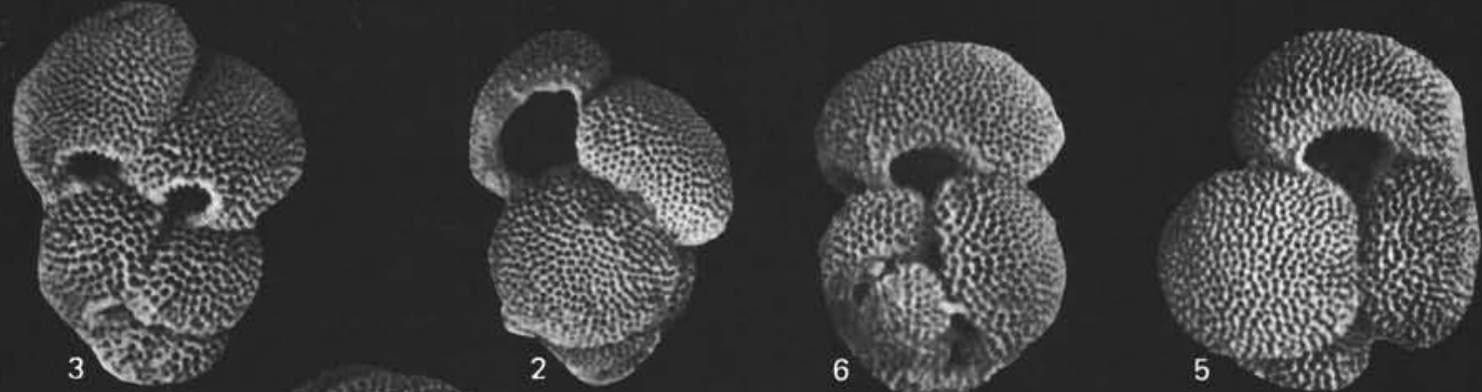

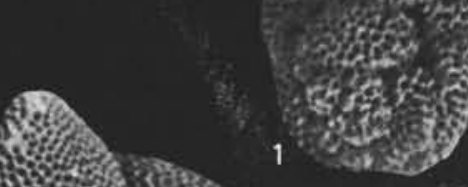

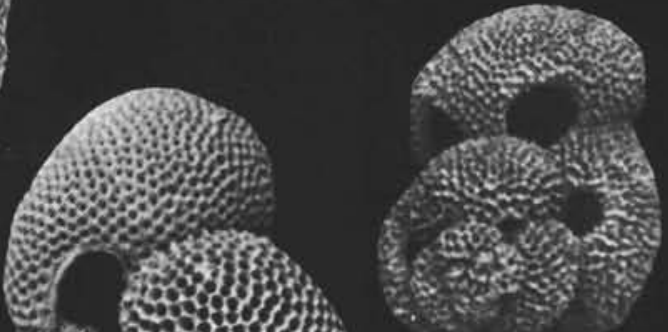

Noristeg\%

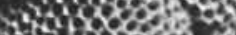

traces:

6. 4 H.

is a

litesy

9

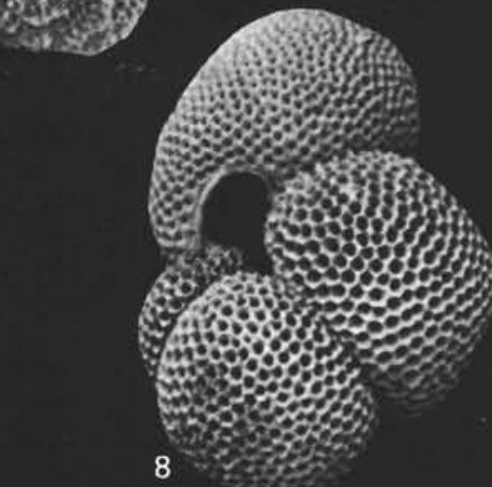

sositis
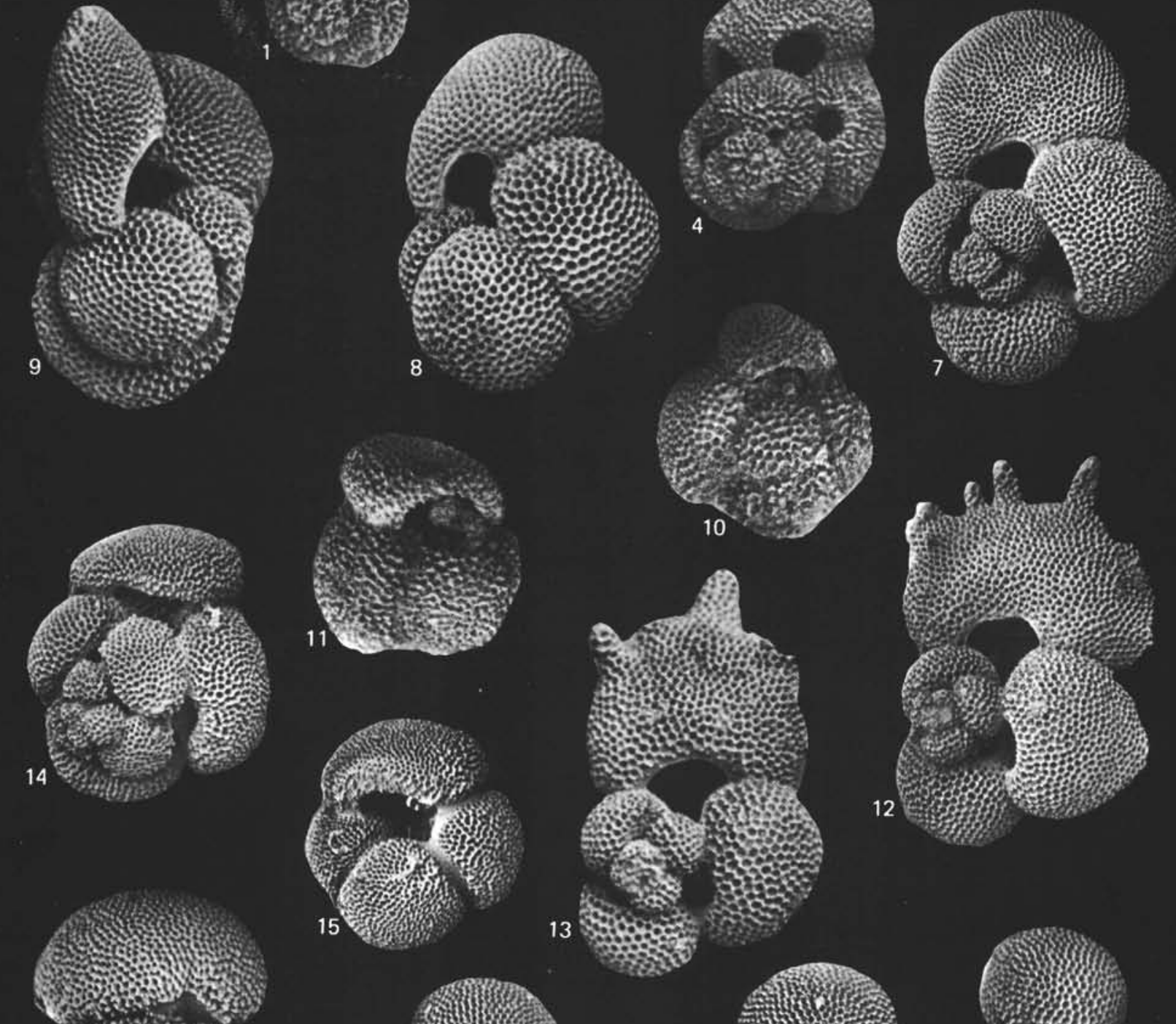

silntos

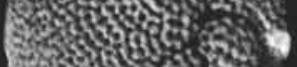

W

Wing
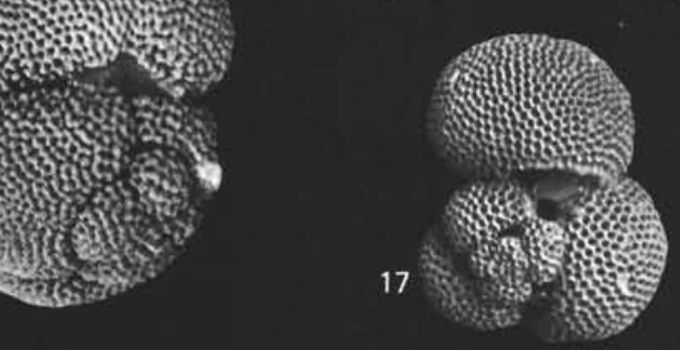

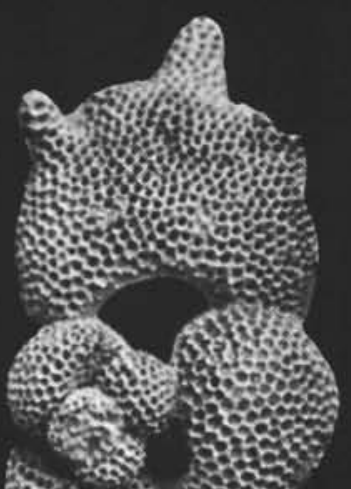

13

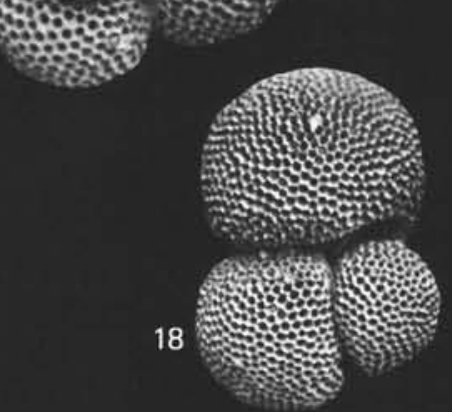

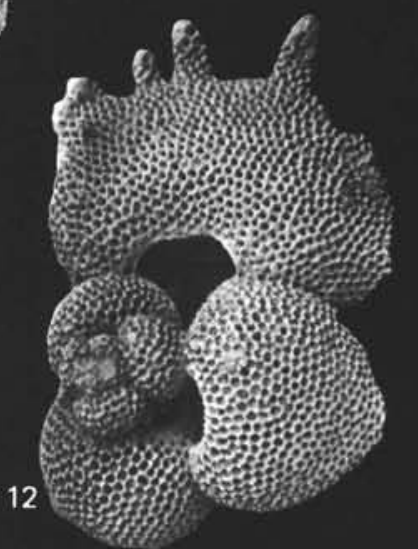

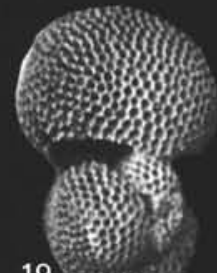

19 tingesy 
PLATE 2

Figure 1 Globigerinoides tenellus Parker. Sample 424B1-1, 40-42 cm, Quaternary, N23. × 116 .

Figures 2, 3 Globigerinoides (?) sp. Sample 424-3-5, 85-87 cm, Quaternary, N23. $\times 73$.

Figure 4 Orbulina universa d'Orbigny. Sample 420-1-2, 49-50 cm, Quaternary, N23. $\times 97$.

Figures 5-10 Globigerinita glutinata (Egger). 5-7: Sample 4251-1, 40-42 cm, Quaternary, N23. × 100. 8-10: Sample 424-4-6, 49-51 cm, Quaternary, N22. $\times 97$.

Figures 11, 12 Candeina nitida d'Orbigny. Sample 423-4-4, 40-42 $\mathrm{cm}$, Quaternary, N22. $\times 116$.

Figures 13-15 Globigerinella siphonifera (d'Orbigny). Sample 424-4-2, 80-82 cm, Quaternary, N22. ×97.

Figures 16, 17 Hastigerina pelagica (d'Orbigny). Sample 423-2-2, 40-42 cm, Quaternary, N23. ×73.

Figures 18-21 Globigerina bulloides d'Orbigny. Sample 425-3-4, 49-51 cm, Quaternary, N22. ×97. 
PLATE 2
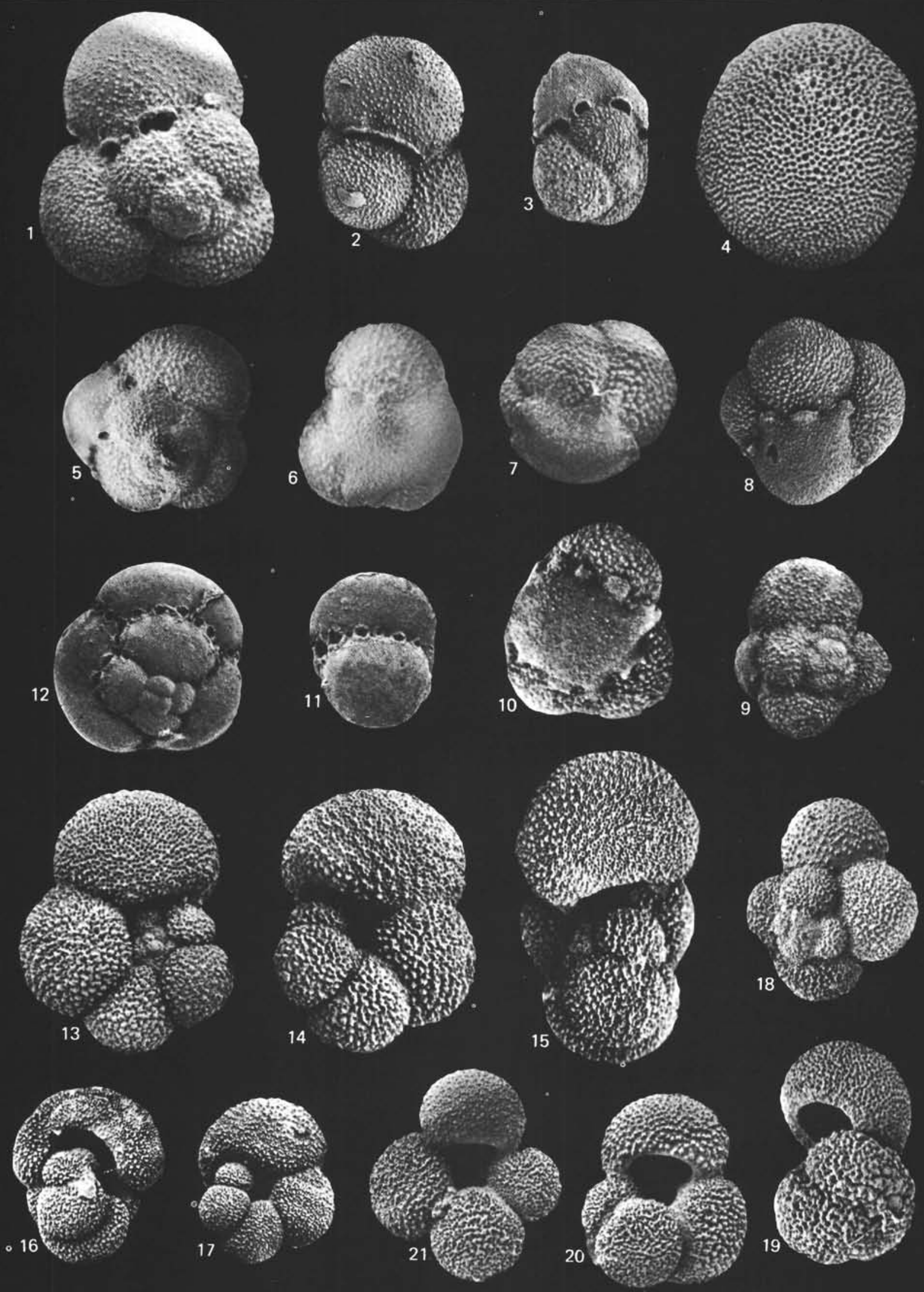


\section{PLATE 3}

Figures 1-7 Globigerina calida calida Parker. 1-4. Sample 425-2-4, 49-51 cm, Quaternary, N23. ×123. 5,7. Sample 423-2-2, 40-42 cm, Quaternary, N23. $\times 123$. 6. Sample 419-3-1, 40-42 cm, Quaternary, N23. $\times 142$.

Figure $8 \quad$ Globigerina (?) quinqueloba Natland. Sample 424A-3-3, 60-62 cm, Quaternary, N22. $\times 71$.

Figures 9-11 Globigerina rubescens Hofker. Sample 423-2-2, 40-42 cm, Quaternary, N23. $\times 95$.

Figures 12-14 Sphaeroidinella dehiscens excavata Banner and Blow. Sample 420-1-3, 49-51 cm, Quaternary, N23. $\times 47$.

Figures 15-18 Globorotaloides hexagonus (Natland). Sample 421-1-1, 40-42 cm, Quaternary, N23. × 105 . 

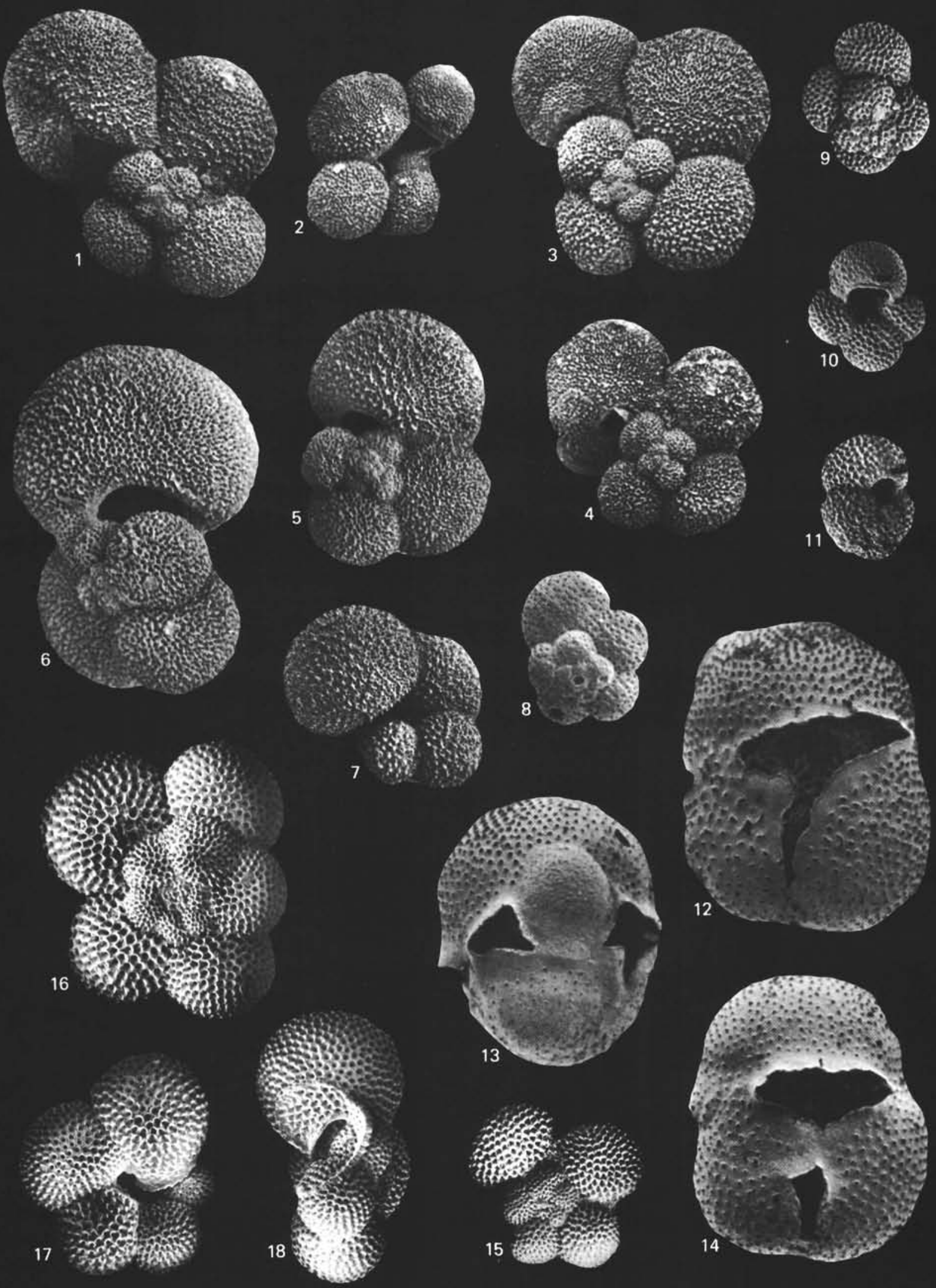


\section{PLATE 4}

Figures 1-3 Neogloboquadrina dutertrei (d'Orbigny). Sample 428-2-2, 109-111 cm, Quaternary, N22. ×114.

Figures 4-7 Globorotalia inflata (d'Orbigny). Sample 425-3-5, 49-50 cm, Quaternary, N22. $\times 95$.

Figures 8-10 Pulleniatina obliquiloculata (Parker and Jones). Sample 425-3-3, 49-51 cm, Quaternary, N22. $\times 95$.

Figure 11 Globorotalia tumida flexuosa (Koch). Sample 421-1-5, 40-42 cm, Quaternary, N23. ×71.

Figures 12-15 Globorotalia tumida tumida (Brady). 12. Sample 420-2-4, 89-91 cm, Quaternary, N23. × 114. 1315. Sample 425-3-6, 49-51 cm, Quaternary, N22. $\times 95$. 


\section{PLATE 4}
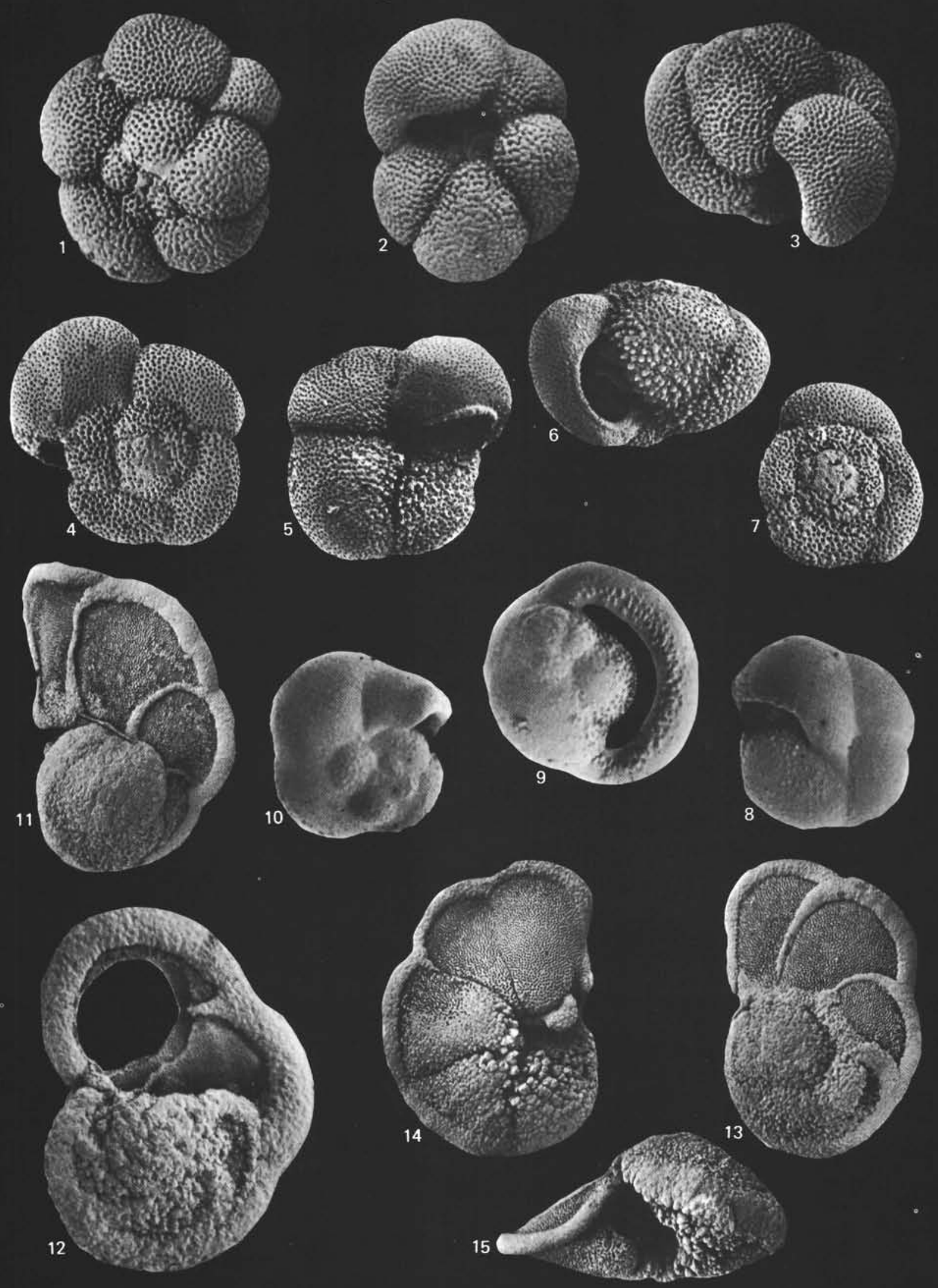


\section{PLATE 5}

Figures 1-4 Globorotalia crassaformis oceanica Cushman and Bermudez. Sample 425-4-2, 49-51 cm, Quaternary, N22. $\times 123$.

Figures 5-8 Globorotalia truncatulinoides (d'Orbigny). 5, 6. Sample 425-5-3, 49-51 cm, Quaternary, N22. $\times 95$. 7-8. Sample 424B-4-3, 70-72 cm, Quaternary, N22. $(7 . \times 95 ; 8 . \times 71)$.

Figures 9-12 Globorotalia fimbriata (Brady). Sample 423-1-3, $50-52 \mathrm{~cm}$, Quaternary, N23. (9. $\times 123 ; 10-12$. $\times 95)$.

Figures 13, 14 Globorotalia pertenuis Beard. Sample 420-12-4, 40-42 cm, upper Pliocene, N21. $\times 71$. 

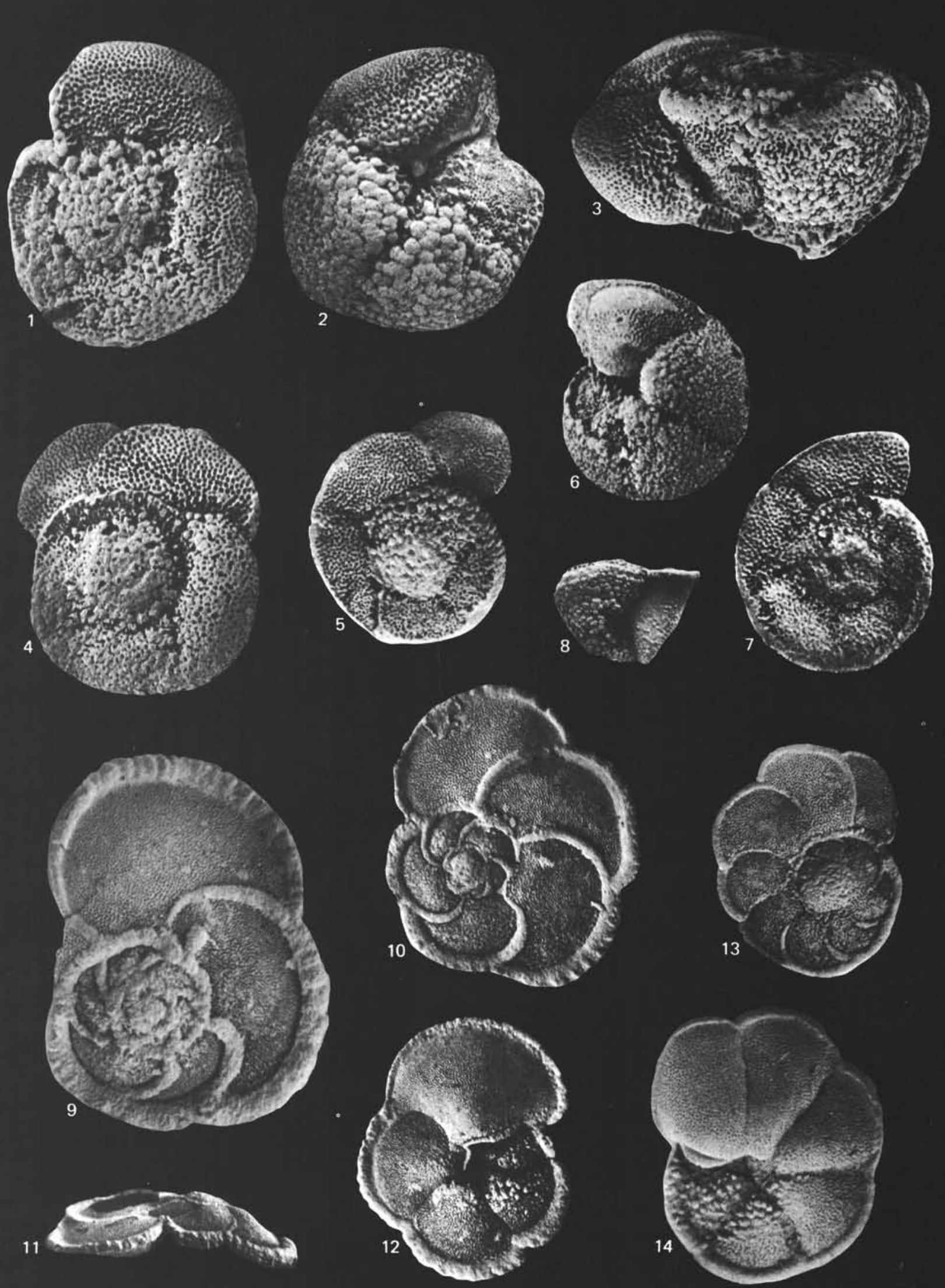


\section{PLATE 6}

Figures 1-7 Globorotalia menardii (Parker, Jones and Brady). 1-4. Sample 422-1-2, 39-41 cm, Quaternary, N23. $\times 95$. 5. Sample 420-6-2, 34-36 cm, Quaternary, N22. $\times 95.6-7$. Sample 434B-3-5, $110 \mathrm{~cm}$, Quaternary, N23. $(6 . \times 75 ; 7 . \times 95)$.

Figures 8-10 Globorotalia pseudomiocenica Bolli and Bermudez. Sample 420-13-1, 40-42 cm, late Pliocene, N21. $\times 95$.

Figures 11-13 Globorotalia ungulata Bermudez. Sample 423-3-2, 40-42 cm, Quaternary, N23. $\times 95$.

Figures 14-16 Globorotalia cavernula Bé . Sample 424-4-2, 80-82 $\mathrm{cm}$, Quatnerary, N22. $\times 95$. 


\section{PLATE 6}
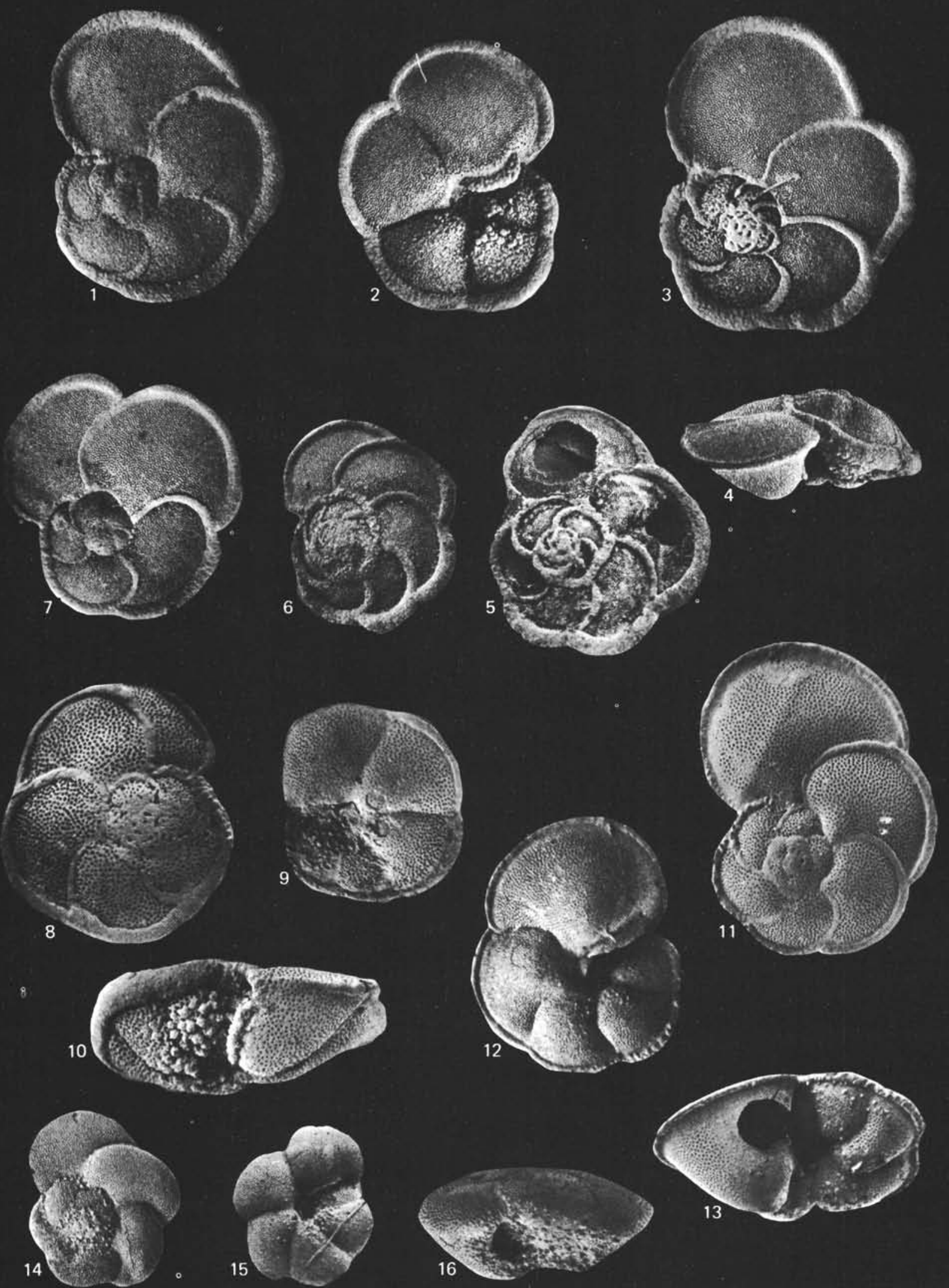


\section{PLATE 7}

Figures 1-3 Globorotalia hirsuta (d'Orbigny). Sample 425-3-6, 49-51 cm, Quaternary, N22. ×116.

Figures 4-6 Globorotalia scitula (Brady). Sample 425-5-2, $49-51 \mathrm{~cm}$, Quaternary, N22. $\times 97$.

Figures 7-12 Globorotalia subscitula Conato. 7-9. Sample 420-10-5, 40-42 cm, Quaternary, N22. ×97. 1012. Sample 419-5-2, 40-42 cm, Quaternary, N22. $\times 116$.

Figures 13-19 Globorotalia cultrata (d'Orbigny). 13. Sample 419-4-3, 39-41 cm, Quaternary, N22. ×97. 14-16. Sample 422-3-1, 39-41 cm, Quaternary, N23. $\times 73$. 17-19. Sample 425-5-1, 49-51 cm, Quaternary, N22. $\times 97$. 

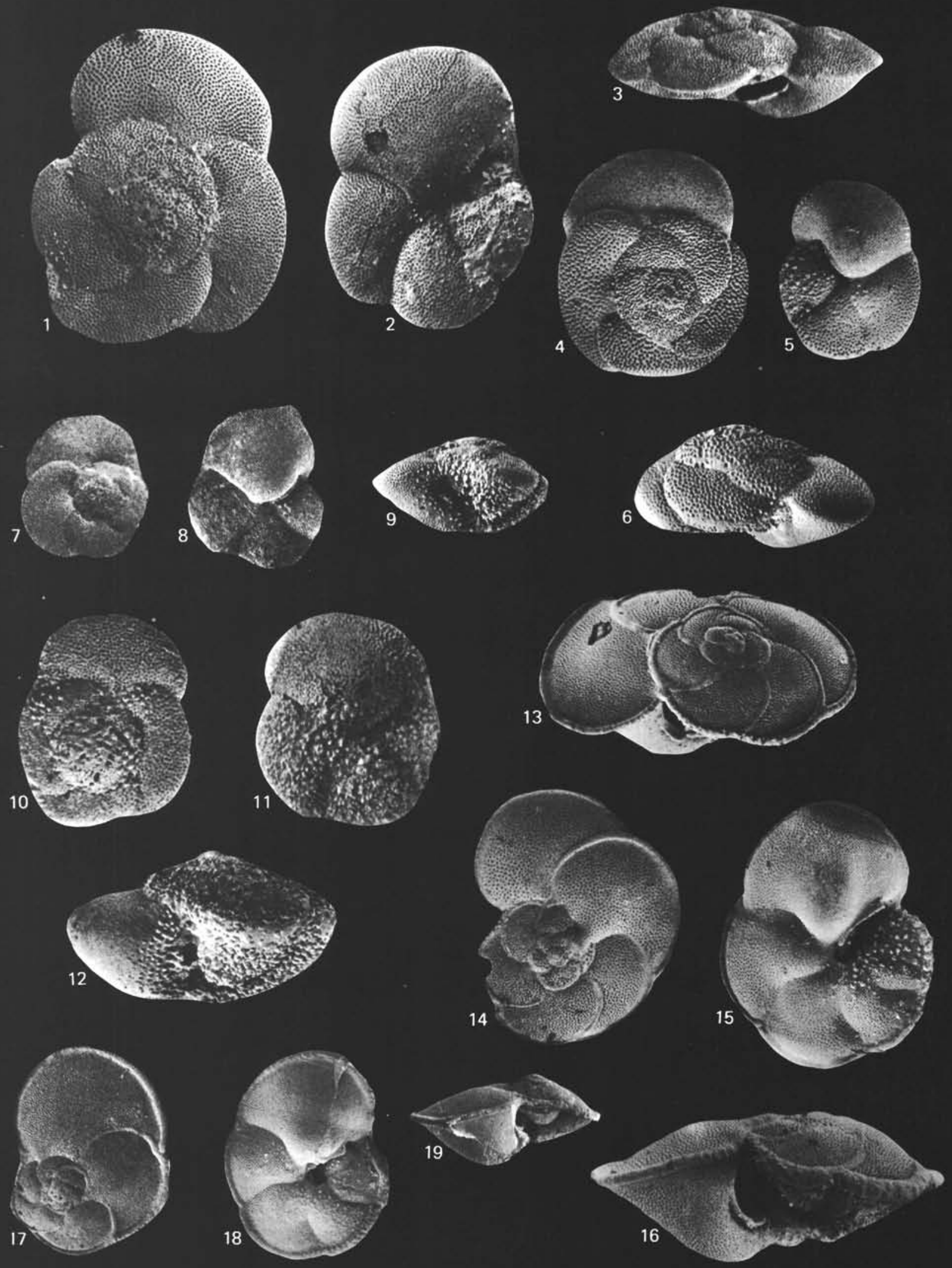